\title{
Trypanosoma cruzi Infection in Genetically Selected Mouse Lines: Genetic Linkage with Quantitative Trait Locus Controlling Antibody Response
}

\author{
Francisca Vorraro, Wafa H. K. Cabrera, Orlando G. Ribeiro, José Ricardo Jensen, \\ Marcelo De Franco, Olga M. Ibañez, and Nancy Starobinas
}

Laboratório de Imunogenética, Instituto Butantan, Avenida Vital Brasil 1500, 05503-900 São Paulo, SP, Brazil

Correspondence should be addressed to Nancy Starobinas; nancy.starobinas@butantan.gov.br

Received 24 April 2014; Revised 15 July 2014; Accepted 16 July 2014; Published 13 August 2014

Academic Editor: Christophe Chevillard

Copyright (C) 2014 Francisca Vorraro et al. This is an open access article distributed under the Creative Commons Attribution License, which permits unrestricted use, distribution, and reproduction in any medium, provided the original work is properly cited.

Trypanosoma cruzi infection was studied in mouse lines selected for maximal (AIRmax) or minimal (AIRmin) acute inflammatory reaction and for high $\left(\mathrm{H}_{\text {III }}\right)$ or low $\left(\mathrm{L}_{\text {III }}\right)$ antibody $(\mathrm{Ab})$ responses to complex antigens. Resistance was associated with gender (females) and strain - the high responder lines AIRmax and $\mathrm{H}_{\mathrm{III}}$ were resistant. The higher resistance of $\mathrm{H}_{\mathrm{III}}$ as compared to $\mathrm{L}_{\mathrm{III}}$ mice extended to higher infective doses and was correlated with enhanced production of IFN- $\gamma$ and nitric oxide production by peritoneal and lymph node cells, in $\mathrm{H}_{\mathrm{III}}$ males and females. We also analyzed the involvement of previously mapped $\mathrm{Ab}$ and $\mathrm{T}$. cruzi response QTL with the survival of Selection III mice to T. cruzi infections in a segregating backcross $\left[\mathrm{F} 1\left(\mathrm{H}_{\mathrm{III}} \times \mathrm{L}_{\mathrm{III}}\right) \times \mathrm{L}_{\mathrm{III}}\right]$ population. An Ab production QTL marker mapping to mouse chromosome $1(34.8 \mathrm{cM})$ significantly cosegregated with survival after acute T. cruzi infections, indicating that this region also harbors genes whose alleles modulate resistance to acute T. cruzi infection.

\section{Introduction}

The protozoan Trypanosoma cruzi, the causative agent of Chagas' disease in humans, parasitizes several other mammalian species. After infection with T. cruzi, the parasites survive and multiply in nucleated cells as amastigotes, eventually reaching the bloodstream as trypomastigote forms. The acute infection phase is characterized by high levels of circulating parasites, while parasite proliferation is contained during the chronic phase [1].

Innate immune responses play critical roles in the control of parasite spreading and host survival. Toll-like receptor (TLR) family of pattern recognition receptors (PRRs) plays a central role in the recognition of $T$. cruzi by the immune system [2]; TLR4 [3], TLR2 [4-6], TLR9 [7], and TLR7 [8] initiate a signaling cascade that culminates in the activation of proinflammatory genes which are important for resistance to T. cruzi infection [9].

NOD1, a member of the cytosolic NOD-like receptor (NLR) family, also plays a role in controlling T. cruzi infection; Nod1-/- mice were shown to be very susceptible to T. cruzi, succumbing to the infection and displaying higher parasitemia and parasite loads in the spleen and heart tissues [10].

Recent works suggest that ASC inflammasomes are critical determinants of host resistance to T. cruzi infection [11]; moreover NLRP3 inflammasome controls parasitemia by inducing NO production via a caspase-1-dependent, IL-1Rindependent pathway [12].

The early control of replication depends largely on nitric oxide (NO) induction in macrophages mediated by gammainterferon (IFN- $\gamma$ ) and tumor necrosis factor alpha (TNF- $\alpha$ ). IFN- $\gamma$ is synthesized shortly after infection, mainly by IL-12 and TNF- $\alpha$ activated NK cells [13-16]. The in vivo inhibition of iNOS results in increased susceptibility to parasites $[17,18]$.

The effector mechanisms that control parasite loads and survival during the acute infection phase also depend on specific cell-mediated immune responses. Mice depleted or deficient in CD4 or CD8 lymphocytes show early mortality and increased numbers of parasites in their bloodstreams and 
tissues [19-21]. As a mechanism of evasion during T. cruzi replication they release immunomodulatory molecules that delay parasite-specific responses mediated by effector $\mathrm{T}$ cells [22].

Resistance to T. cruzi infection in humans as well as mice may vary according to the genetic background of the host and the virulence of the parasite strain [23, 24]. Genetic control of responses to T. cruzi is governed by multiple genes, and mice of different strains can develop infections that evolve towards either early death or a chronic phase [25].

Silva et al. [26] recently analyzed the susceptibility of several inbred mouse lines to infection with the $\mathrm{Y}$ strain of T. cruzi and found that susceptibility varied among those lines, especially between $\mathrm{A} / \mathrm{J}$ and $\mathrm{C} 57 \mathrm{BL} / 6$ mice. A/J mice are extremely susceptible, with $100 \%$ death rates, whereas C57BL/6 mice are resistant. Data obtained with an F1 (A/J x $\mathrm{C} 57 \mathrm{BL} / 6 \mathrm{~J})$ population suggested the existence of one or more loci mapping on chromosome $\mathrm{X}$ that contribute to resistance to T. cruzi infections.

In addition to these inbred mouse lines, the involvement of different genetic backgrounds in infection control has been analyzed in mice lines selected for either high $(\mathrm{H})$ or low (L) antibody responses and maximal (AIRmax) and minimal (AIRmin) acute inflammatory reactivity (AIR). Starting from a genetically heterogeneous founder population $\left(\mathrm{F}_{0}\right)$ of Albino Swiss mice, the selection of lines for antibody responsiveness (named Selection III) was carried out using assortative mating in successive generations based on secondary antibody response to Salmonellae flagellar antigens. This bidirectional selective pressure resulted in the accumulation of alleles at multiple quantitative trait loci (QTLs) in each $\mathrm{H}$ and $\mathrm{L}$ line endowed with opposite modulatory effects on the various steps of antibody biosynthesis [27]. The differences in antibody responses between $\mathrm{H}_{\mathrm{III}}$ and $\mathrm{L}_{\mathrm{III}}$ lines are not restricted just to the selection immunogen but encompass a wide range of complex antigens, showing evidence for multispecific effects of the relevant genes [28, 29]. Genetic analyses indicated that 5-10 QTLs regulate the antibody production phenotype, and a QTL mapping experiment using microsatellite markers yielded three highly significant QTLs on chromosomes 3, 8, and 9 [30]. $\mathrm{H}_{\text {III }}$ and $\mathrm{L}_{\text {III }}$ lines also show extreme divergence in other phenotypes, such as skin carcinogenesis [31] and pristane induced arthritis-PIA. Our group successfully detected a PIA-susceptibility QTL on chromosome 3 by examining the cosegregation of the most significant Ab QTL markers with arthritis phenotypes [32].

Selection for acute inflammatory response was carried out in a similar manner, using polyacrylamide beads (Biogel $\mathrm{P}-100$ ), with induced local inflammatory influx and exudated protein concentrations as the selection phenotypes $[33,34]$. Analysis of this selective process indicated that AIR regulation involves at least 11 QTLs [35]. Significant interline differences were also observed in response to several phlogistic agents, including carrageenan, zymosan, and inactivated bacteria [35]. These mouse lines have been used to study the effects of genetic control of nonspecific immunity on susceptibility to neoplastic [36], autoimmune [37], and infectious diseases [38].
The selective process did not affect specific immune responses, as both AIRmax and AIRmin mice produced similar amounts of antibodies after immunization with optimal doses of complex antigens (such as heterologous proteins and bacterial antigens). Cell-mediated immune responses, such as T-cell specific proliferation and delayed-type hypersensitivity reactions, were also similar in both lines. On the other hand, these lines differ in natural resistance to pristane induced arthritis [37], various bacterial infections [38], lung [39], kidney [40], and colon [41] chemical carcinogenesis, as well as wound-healing capacities [42].

The relative contributions of innate and specific immune responses to $T$. cruzi infections have not yet been determined, nor their genetic influences on infection susceptibility. In this study we analyzed the relationships between the genetic controls involved in antibody production and inflammatory responses and resistance to $T$. cruzi infection by examining the course of parasite infection in mice selected for high $\left(\mathrm{H}_{\mathrm{III}}\right)$ and low $\left(\mathrm{L}_{\mathrm{III}}\right)$ antibody responses (Selection III) or for maximal (AIRmax) and minimal (AIRmin) acute inflammatory responses (AIR).

\section{Materials and Methods}

2.1. Mice and Crosses. Male and female 8-12-week-old mice were used in all experiments. All stock mice and crosses used were developed and maintained at the animal facilities of the Immunogenetics Laboratory at the Butantan Institute, São Paulo State, Brazil. All animals received humane care according to criteria outlined in the Ethical Principles in Animal Research Guidelines adopted by the Brazilian College of Animal Experimentation. Experiments were approved (protocol no. 066/02) by the Committee on Ethics in the use of Animals of the Biomedical Sciences Institute-USP.

AIRmax and AIRmin mice were selected from a polymorphic foundation population constructed by the balanced intercrossing of eight inbred mouse lines (A/J, DBA2/J, SWR/J, CBA/J, SJL/J, BALB/cJ, P/J, and $\mathrm{C} 57 \mathrm{BL} / 6 \mathrm{~J})$, as described in detail elsewhere [35]. Although the formal stock designations are Ibut: AIRH and Ibut: AIRL, we refer to them in this paper and in previous publications as AIRmax and AIRmin, respectively.

The selection for high $\left(\mathrm{H}_{\mathrm{III}}\right)$ and low $\left(\mathrm{L}_{\mathrm{III}}\right)$ antibody responder mice (Selection III) was described in detail elsewhere [27].

Inbred $\mathrm{H}_{\mathrm{III}}$ and $\mathrm{L}_{\mathrm{III}}$ lines derived from their respective outbred stocks were used to produce $\mathrm{F} 1\left(\mathrm{H}_{\mathrm{III}} \times \mathrm{L}_{\mathrm{III}}\right)$ hybrid mice and 242 backcrossed $\left(\mathrm{F} 1 \times \mathrm{L}_{\text {III }}\right)$ segregating $(\mathrm{Bc}-\mathrm{L})$ mice for genetic studies.

Nonselected Swiss Albino male mice purchased from the Central Animal Facilities at the Butantan Institute were used for in vivo maintenance of T. cruzi.

\subsection{Experimental Infections, Mortality Rates, and Parasitemia} Determinations. The CL strain of Trypanosoma cruzi was used in all experiments. The parasite was maintained in vivo by serial passage of the parasite blood forms in Swiss Albino mice. 
Mice were s.c. infected with T. cruzi blood forms diluted at the indicated concentrations in $100 \mu \mathrm{L}$ PBS buffer and monitored daily for deaths. Parasitemia levels were determined by hemocytometer counts of trypomastigotes in fresh blood samples diluted in ammonium oxalate (1\%).

2.3. Cell Cultures. Mice were euthanized at $0,7,15$, and 20 days after infection with $1 \times 10^{2}$ parasites. Their peritoneal cavities were washed with $5 \mathrm{~mL}$ of PBS under sterile conditions, and the cells were pelleted and then resuspended in complete RPMI-1640 medium (RPMI-1640 supplemented with $2 \mathrm{mM}$ L-glutamine, $10 \mathrm{~g} / \mathrm{mL}$ gentamicin, and $10 \%$ fetal calf serum). The cells $\left(2 \times 10^{5} /\right.$ well $)$ were cultured for $48 \mathrm{~h}$ at $37^{\circ} \mathrm{C}$ and $5 \% \mathrm{CO}_{2}$ in a final volume of $100 \mu \mathrm{L} /$ well in 96 -well flat-bottom plates with or without stimulation with ConA $(2.5 \mu \mathrm{g} / \mathrm{mL})$.

Lymph node and spleen cell suspensions were obtained by homogenizing those organs in glass grinders with RPMI1640 medium under sterile conditions and then washing and diluting the cells to $1 \times 10^{7}$ cells $/ \mathrm{mL}$ in modified Click medium (RPMI-1640 supplemented with $0.05 \mathrm{mM}$ 2-mercaptoethanol, $2 \mathrm{mM}$ L-glutamine, $1 \mathrm{mM}$ sodium pyruvate, $10 \mathrm{~g} / \mathrm{mL}$ gentamicin, and $2 \%$ heat-inactivated normal mouse serum) to a final volume of $1 \mathrm{~mL} /$ well in 24 -well flat-bottom plates. The cells were stimulated with ConA $(2.5 \mu \mathrm{g} / \mathrm{mL})$ and cultured for $48 \mathrm{~h}$ at $37^{\circ} \mathrm{C}$ and $5 \% \mathrm{CO}_{2}$. Cell-free culture supernatants were harvested and stored at $-20^{\circ} \mathrm{C}$.

2.4. IFN- $\gamma$ Detection. Unlabeled XMG1.2 $(5 \mu \mathrm{g} / \mathrm{mL})$ and biotinylated AN-18 $(5 \mu \mathrm{g} / \mathrm{mL})$ rat anti-mouse IFN- $\gamma$ monoclonal antibodies were used in two-site sandwich ELISA assays using an alkaline avidin-phosphatase and pnitrophenyl phosphate substrate in Tris- $\mathrm{NaCl}$ buffer to detect IFN- $\gamma$ contents in supernatants of 48-hour cultured lymph node or spleen cells. Absorbance at $405 \mathrm{~nm}$ was measured in a Multiskan MS plate reader (Labsystems, Finland), and IFN- $\gamma$ concentrations were determined by comparisons with a standard curve obtained from serial dilutions of recombinant IFN- $\gamma$.

2.5. Nitric Oxide (NO) Quantification. Forty-eight-hour cellfree peritoneal culture supernatants were assayed for $\mathrm{NO}_{2}$ using the Griess reaction. Briefly, $50 \mu \mathrm{L}$ of culture supernatant was incubated with $50 \mu \mathrm{L}$ of a mixture of $1 \%$ sulfanilamide and $0.1 \% \mathrm{~N}$-(1-naphthyl) ethylenediamine dihydrochloride in $2.5 \%$ orthophosphoric acid $\left(\mathrm{H}_{3} \mathrm{PO}_{4}\right)$ at room temperature for $10 \mathrm{~min}$. Absorbance was measured at $540 \mathrm{~nm}$ using a Multiskan MS plate reader (Labsystems); the micromolar concentrations of $\mathrm{NO}_{2}$ were determined by interpolation from a $\mathrm{NaNO}_{2}$ standard curve.

2.6. Quantification of T. cruzi DNA in Cardiac Muscle by Real-Time PCR. Genomic DNA from mouse cardiac muscle was isolated using DNeasy Tissue kit (Qiagen, Germany) following the manufacturer's instructions. The primer pairs TCZ-F: 5'-GCT CTT GCC CAC CMG GGT GC-3' (where $\mathrm{M}=\mathrm{A}$ or $\mathrm{C}$ ) and TCZ-R: $5^{\prime}$-CCA AGC AGC GGA TAG TTC AGG-3' were used in qPCR to detect the target T. cruzi 195-bp repeat DNA in the cardiac muscles of infected mice. In parallel, primers for the murine specific TNF-single copy genomic sequence (TNF-5241: $5^{\prime}$-TCC CTC TCA TCA GTT CTA TGG CCC A-3' and TNF-5411: $5^{\prime}$-CAG CAA GCA TCT ATG CAC TTA GAC CCC- $3^{\prime}$ ) were used in a parallel assay as an internal control to normalize the amount of host DNA loaded in each reaction, as described by Cummings and Tarleton [43].

Normalization was obtained by calculating the ratios of the concentrations of target T. cruzi DNA and murine TNFreference gene DNA in the same tissue sample.

Real-time PCR was carried out with $65 \mathrm{ng}$ of sample DNA, $12.5 \mu \mathrm{L}$ QuantiTect SYBR Green PCR Master Mix (Qiagen), $0.5 \mathrm{M}$ of each primer, and nuclease-free water to a final volume of $25 \mu \mathrm{L}$. The reactions were run in a PTC200 thermocycler (MJ Research, Inc., USA) with an initial step of $15 \mathrm{~min}$ at $95^{\circ} \mathrm{C}$ followed by 50 denaturation cycles $(20 \mathrm{~s}$ at $\left.95^{\circ} \mathrm{C}\right)$, annealing $\left(20 \mathrm{~s}\right.$ at $\left.55^{\circ} \mathrm{C}\right)$, and extension $(1 \mathrm{~min}$. at $\left.72^{\circ} \mathrm{C}\right)$. Fluorescence intensity was detected at the end of each extension phase using a Chromo 4 detector (MJ Research). Melt curves of the products were obtained after the amplification phase. All data was analyzed using Opticon Monitor Analysis Software v2.03 (MJ Research).

In order to estimate target T. cruzi DNA concentrations (and therefore the parasite load of each sample), a standard curve was constructed through serial dilutions (ranging from 10,000 to 10 parasite equivalents) of gDNA obtained from uninfected cardiac tissue with $10^{4} \mathrm{~T}$. cruzi trypomastigotes artificially added. The standard curve derived from these dilutions (log transformed) indicated the amounts of parasite equivalents in each sample (adapted from [43]).

\subsection{Genotyping the Polymorphic Microsatellite Markers of} Antibody-Controlling QTL (Ab QTL) in Selection III. For genomic DNA extraction, frozen mouse tail tips were incubated at $65^{\circ} \mathrm{C}$ for $1 \mathrm{~h}$ in $100 \mu \mathrm{L}$ of lysis buffer containing $50 \mathrm{mM}$ Tris- $\mathrm{HCl}$ ( $\mathrm{pH} 8.0$ ), 10 mM EDTA (pH 8.0), 0.5\% SDS, with $1.5 \mathrm{mg} / \mathrm{mL}$ proteinase $\mathrm{K}$ (Invitrogen). Following another addition of $100 \mu \mathrm{L}$ of lysis buffer, incubation for $15 \mathrm{~min}$, and centrifugation $(13,000 \times \mathrm{g} / 10 \mathrm{~min})$, the supernatants were mixed with 0.1 volumes of $3 \mathrm{M}$ sodium acetate $(\mathrm{pH} 5.2)$ and 2 volumes of $100 \%$ ethanol. The precipitated DNA was washed, dried at room temperature, and dissolved in sterile nucleasefree water.

The genotyping of the Ab QTL microsatellite markers, as described by De Souza et al. [30], was carried out by PCR amplification of $100 \mathrm{ng}$ of DNA using specific primers (Research Genetics, Birmingham, CA). PCR reactions were incubated for $2 \mathrm{~min}$ at $94^{\circ} \mathrm{C}$, followed by 35 cycles of 30 $\mathrm{s} / 94^{\circ} \mathrm{C}, 35 \mathrm{~s} / 55-57^{\circ} \mathrm{C}$, and $45 \mathrm{~s} / 72^{\circ} \mathrm{C}$, followed by a final extension for $7 \mathrm{~min}$ at $72^{\circ} \mathrm{C}$. Individual genotypes of the 242 backcrossed $\left(\mathrm{Bc}-\mathrm{L}_{\mathrm{III}}\right)$ mice for each marker were determined by comparing their PCR fragment sizes (as visualized in $4.5 \%$ agarose gels) with those of the parental lines.

2.8. Statistical and Genetic Analyses. Groups of infected mice were submitted to Survival Analysis. Means were compared by analysis of variance (ANOVA) and multiple comparison 
Tukey post hoc tests. Differences between the groups were indicated when $P<0.05$.

Individual genetic and phenotypic data from the 242 Bc-L $\mathrm{L}_{\mathrm{III}}$ segregant mice were analyzed using MapManager QTX software $[44,45]$ to determine the significance of the association between marker genotypes and the T. cruzi infection phenotypes. Due to the striking gender difference in infection survival, the $\log _{n}$ normalized data was analyzed considering sex as a covariate for traits.

Critical LRS (likelihood ratio statistic) values corresponding to suggestive $(P<0.63)$, significant $(P<0.05)$, or highly significant $(P<0.001)$ linkage [46] were determined by Random Permutation Testing [47].

\section{Results}

3.1. Mortality Rates. Mortality rates, monitored at doses ranging from 10 to $10^{4}$ blood forms, showed marked genderrelated differences in susceptibility to acute infection in all of the mouse lines analyzed. Males were more susceptible than their respective littermate females (Figures 1 and 2). In addition, we observed divergent levels of resistance in both the AIR (Figure 1) and Selection III (Figure 2) lines.

AIRmax males were significantly more resistant to infection with 10 parasites than AIRmin males (Figure 1(a)), while no differences were observed at higher infective doses (Figures 1(b) and 1(c)). AIRmax females were likewise more resistant than AIRmin females, showing no mortality when challenged with 10 and $10^{2}$ parasites; AIRmin females inoculated with $10^{2}$ trypomastigotes showed high mortality rates (Figure 1(b)) and different survival curves. Infection with more than $10^{2}$ parasites, however, resulted in similar susceptibilities in females of both AIR lines (Figure 1(c)).

Both $\mathrm{H}_{\mathrm{III}}$ and $\mathrm{L}_{\mathrm{III}}$ male mice had high and similar mortality rates (Figures $2(\mathrm{a}), 2(\mathrm{~b})$, and $2(\mathrm{c})$ ) when infected. $\mathrm{L}_{\mathrm{III}}$ male mice died earlier than $\mathrm{H}_{\mathrm{III}}$ animals, however, resulting in significantly different survival curves when infected with $10,10^{2}$, and $10^{4}$ parasites.

Female $\mathrm{H}_{\mathrm{III}}$ mice were more resistant than $\mathrm{L}_{\mathrm{III}}$ females independent of the challenge dose, with clearly different survival curves and mortality rates (Figures 2(a), 2(b), and 2(c)). While only one $\mathrm{H}_{\mathrm{III}}$ female died when challenged with the highest dose, mortality was already significant at the lowest dose among $\mathrm{L}_{\mathrm{III}}$ females, reaching 100\% after challenges with $10^{4}$ parasites. Female $\mathrm{L}_{\mathrm{III}}$ mice mortality was similar to that of the extremely susceptible $\mathrm{L}_{\text {III }}$ males (Figure 2(c)).

3.2. Parasitemia. Males and females of all mouse lines tested developed similar parasitemia peaks in acute T. cruzi infections, independent of initial parasite challenges (representative plots for the $10^{2}$ dose are shown in Figure 3).

Differences related to both gender and lines were observed in parasite-clearance in these mice. Thus, except for a few AIRmax males that cleared blood parasite forms to undetectable levels, the other males died after acute infection (showing high levels of circulating parasites).
High percentages of females from AIRmin $(60 \%)$ and $\mathrm{L}_{\mathrm{III}}$ (100\%) susceptible lines died without showing any effective control of parasitemia levels, whereas all females of resistant AIRmax and $\mathrm{H}_{\mathrm{III}}$ lines cleared blood parasites during acute T. cruzi infection.

Differences in parasitemia control among $\mathrm{H}_{\mathrm{III}}$ and $\mathrm{L}_{\mathrm{III}}$ females in the acute infection phase were not correlated with parasite loads in cardiac tissue in the late phase (150 days after challenging) (Figure 4). This correlation could not be determined in males because all $\mathrm{L}_{\mathrm{III}}$ males died during the acute phase. Gender-related differences were observed in $\mathrm{H}_{\mathrm{III}}$ mice in terms of the amounts of T. cruzi genomic DNA found in their cardiac tissue, with higher values being found in males than in females of both lines (Figure 4). This data indicates that males differ from females not only in terms of the lethality of infection and of parasitemia control, but also in terms of parasite burdens in heart tissue.

3.3. Gamma Interferon and NO Production. Production of IFN- $\gamma$ and nitric oxide (NO) in the acute phase of $T$. cruzi infection was investigated to evaluate whether these mediators were associated with the different levels of infection resistance in mice selected for $\mathrm{AIR}$ or $\mathrm{Ab}$ response phenotypes.

Increases in both IFN- $\gamma$ and $\mathrm{NO}$ production were observed in infected AIRmax and AIRmin mice, but the increases were similar in both lines and did not correlate with either strain-related or gender-related differences in resistance (data not shown).

Lines selected for $\mathrm{Ab}$ response, on the other hand, showed distinct IFN- $\gamma$ production patterns that increased significantly at 7 days and remained elevated 15 days after infection in $\mathrm{H}_{\mathrm{III}}$ males and females; in $\mathrm{L}_{\mathrm{III}}$ mice, IFN- $\gamma$ production was similar to noninfected control levels at all time points (Figure 5(a)). Our data also suggests that IFN- $\gamma$ production influences $\mathrm{NO}$ synthesis during acute infection as increases in this trypanocidal mediator were observed in both $\mathrm{H}_{\text {III }}$ males and females (Figure 5(b)) after, or at the same time as, IFN- $\gamma$ detection. NO levels did not differ between infected and control $\mathrm{L}_{\mathrm{III}}$ mice. Similar profiles of IFN- $\gamma$ and NO secretion were observed with lymph node, peritoneal, and spleen cells (data not shown). Interestingly, we observed the same patterns of IFN- $\gamma$ and NO production with males and their littermate females, so that no correlations between the production of these mediators and gender-related resistance to infection could be established in any of the mouse lines studied.

3.4. QTL Analyses of Responses to T. cruzi Infection. The quantitative trait loci (QTLs) controlling Ab production in Selection III lines had been previously mapped in genome-wide screening with polymorphic genetic markers (microsatellites) [18]. We therefore investigated the participation of these chromosomal regions in the response to T. cruzi infection. Inbred subpopulations of $\mathrm{H}_{\mathrm{III}}$ and $\mathrm{L}_{\mathrm{III}}$ lines that showed the same resistance pattern to T. cruzi infections as the outbred parental lines described above were used for this purpose.

F1 $\left(\mathrm{H}_{\mathrm{III}} \times \mathrm{L}_{\mathrm{III}}\right)$ hybrids, obtained by reciprocal crosses $\left(\mathrm{H}_{\text {III }}\right.$ males $\mathrm{X} \mathrm{L}_{\text {III }}$ females or $\mathrm{H}_{\text {III }}$ females $\mathrm{x} \mathrm{L}_{\text {III }}$ males), showed 

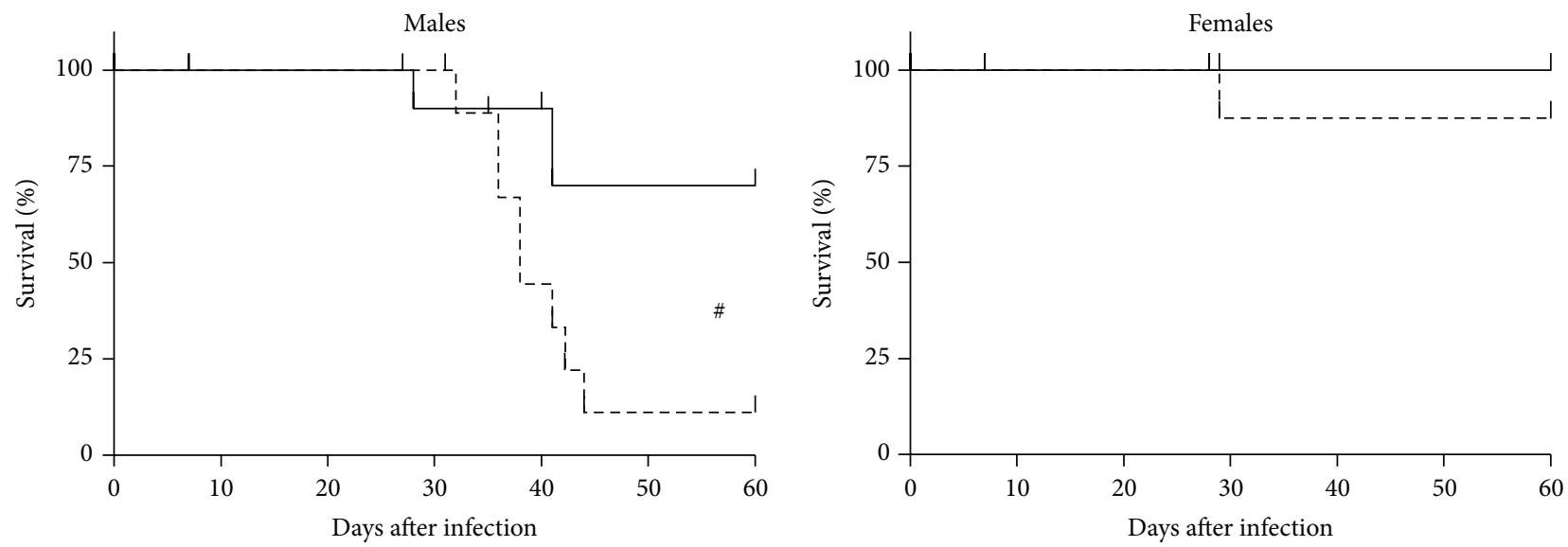

(a)
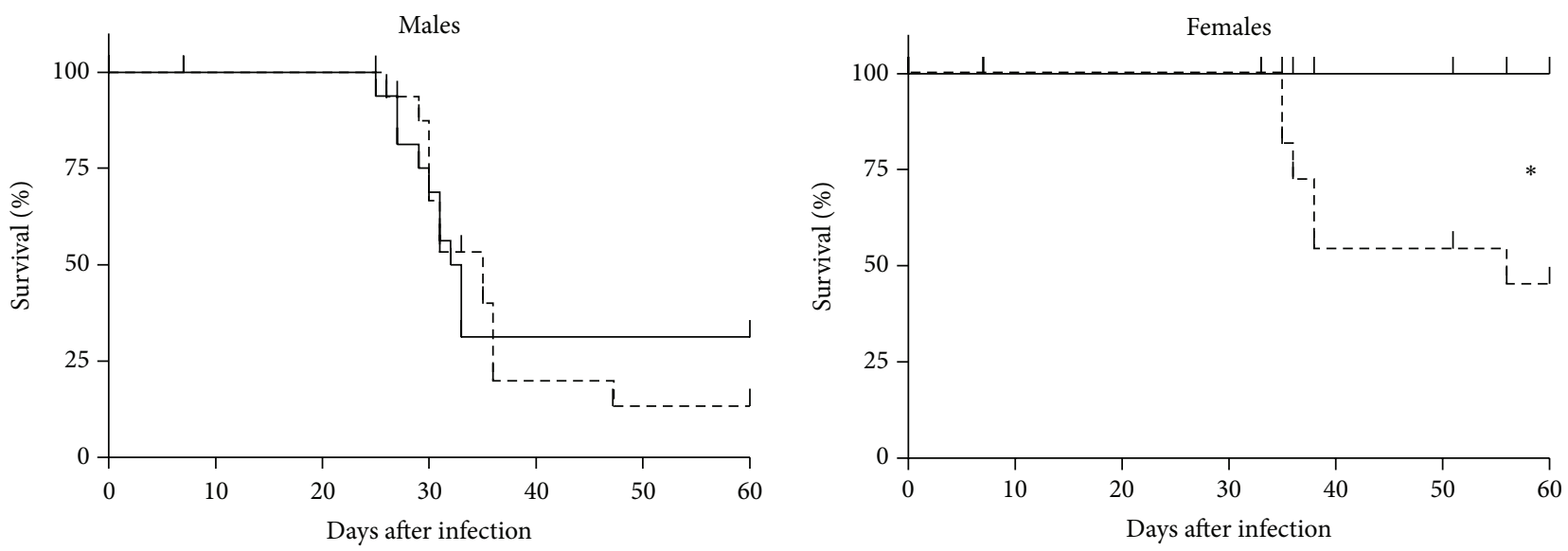

(b)
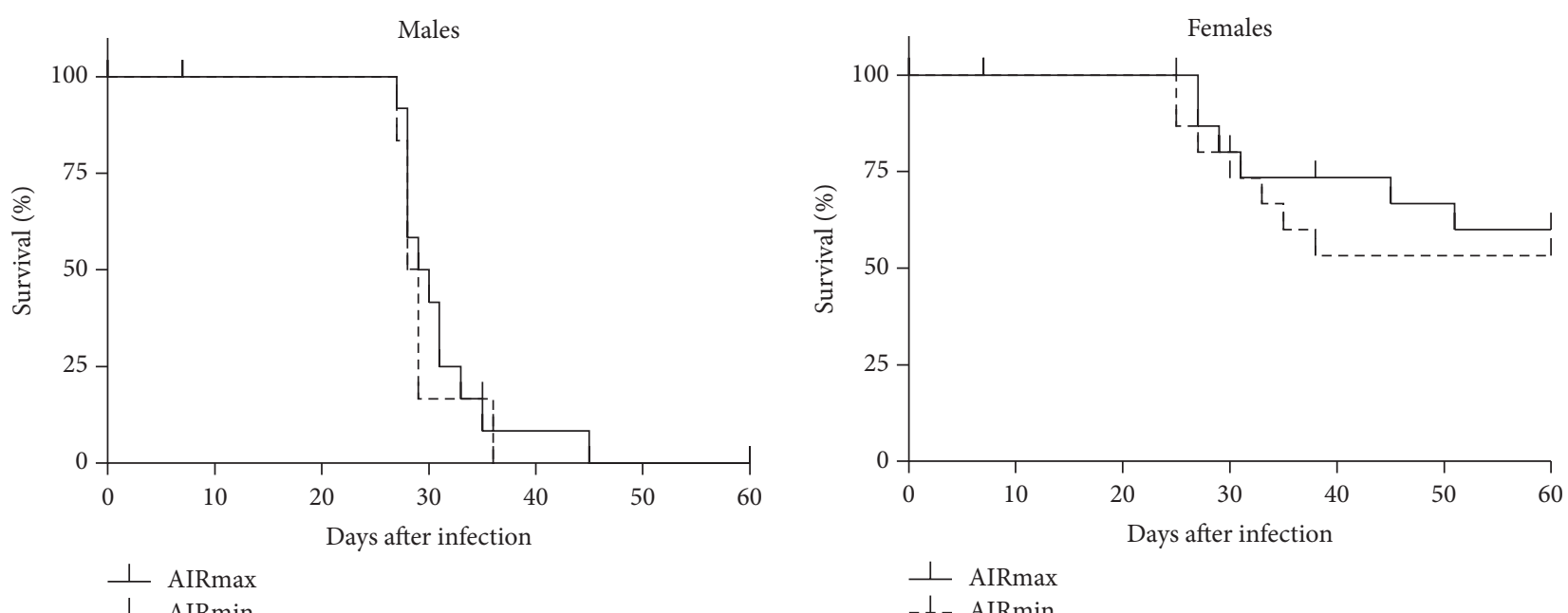

(c)

FIGURE 1: Survival curves of AIR mice after T. cruzi infection. AIRmax and AIRmin mice were infected (s.c.) with 10 (a), $10^{2}$ (b), or $10^{3}$ (c) of CL strain trypomastigote forms. Interline differences evaluated by survival curve analyses of each group $(n=8)$ are indicated for males $\left({ }^{*} P=0.04\right)$ and females $\left({ }^{*} P=0.003\right)$. 

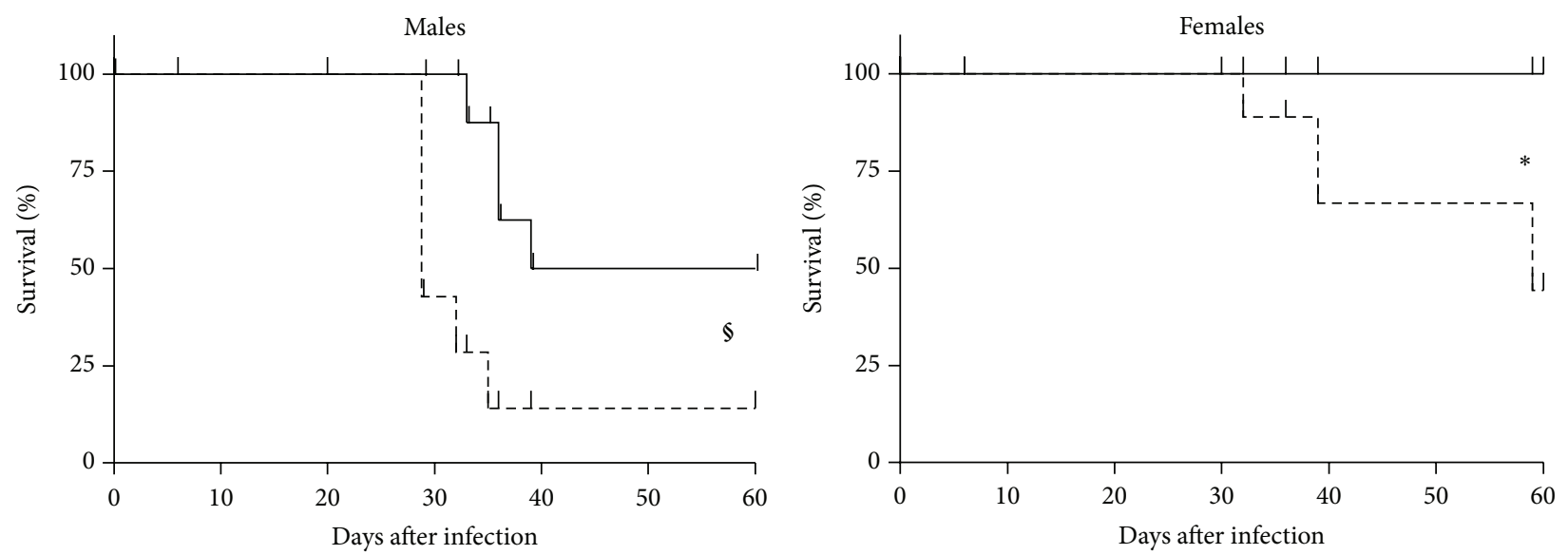

(a)
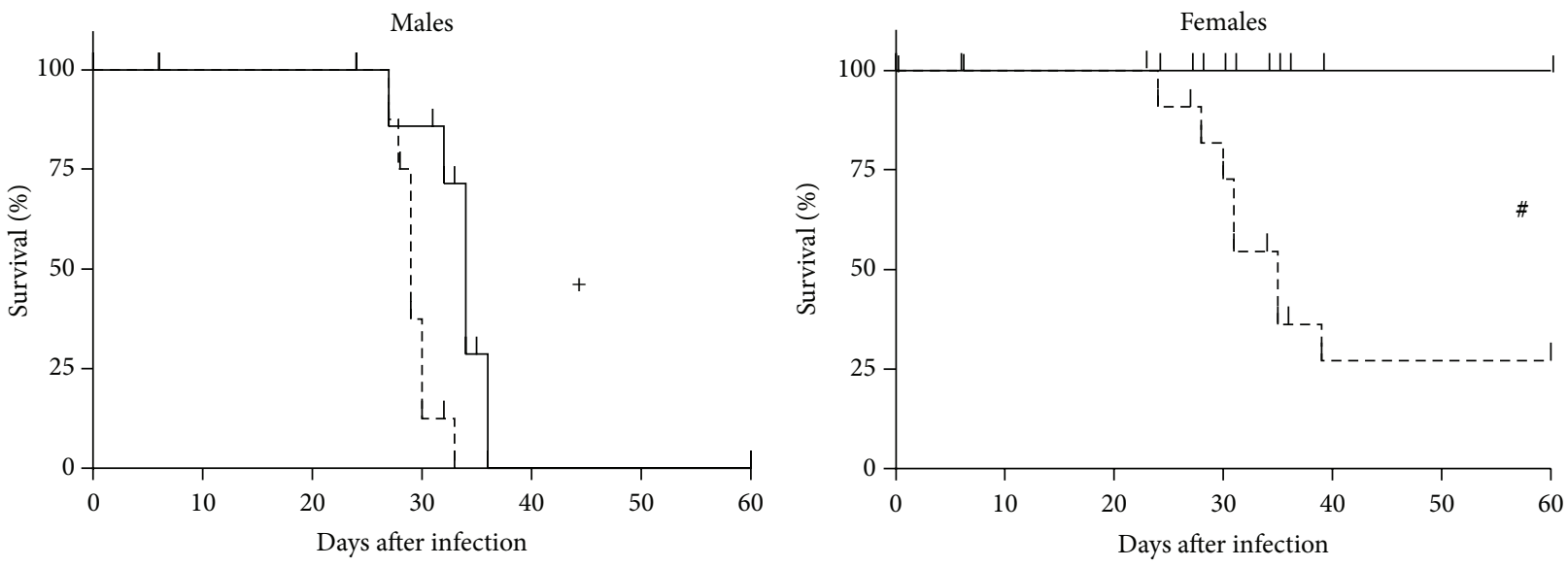

(b)
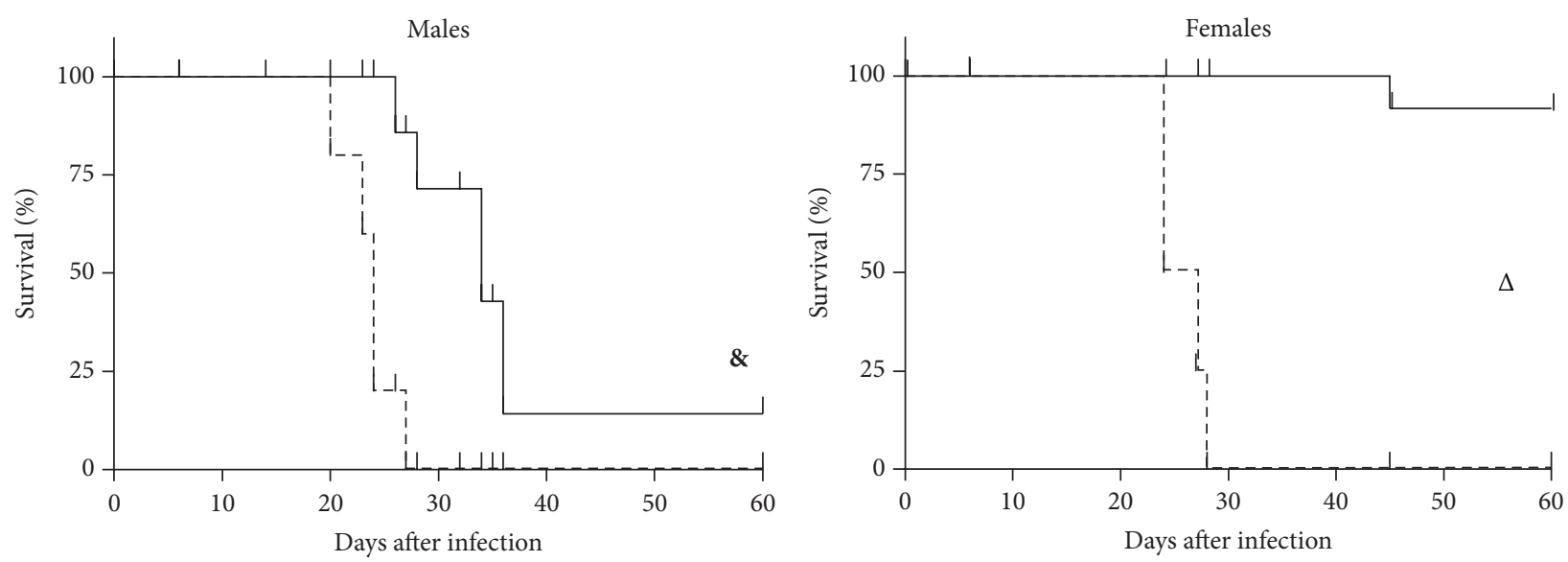

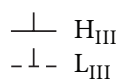

$\perp \mathrm{H}_{\mathrm{III}}$

-1 - L LII

(c)

FIGURE 2: Survival curves of Selection III mice after T. cruzi infection. $\mathrm{H}_{\text {III }}$ and $\mathrm{L}_{\text {III }}$ mice (outbred stock) were infected (s.c.) with 10 (a), $10^{2}$ (b), or $10^{4}(\mathrm{c})$ of CL strain trypomastigote forms. Interline differences evaluated by survival curve analyses of each group $(n=8)$ are indicated for males $\left({ }^{\S} P=0.018 ;{ }^{+} P=0.05 ;{ }^{\circledR} P=0.008\right)$ and females $\left({ }^{*} P=0.015 ;{ }^{\#} P=0.0008 ;{ }^{\Delta} P<0.0001\right)$. 

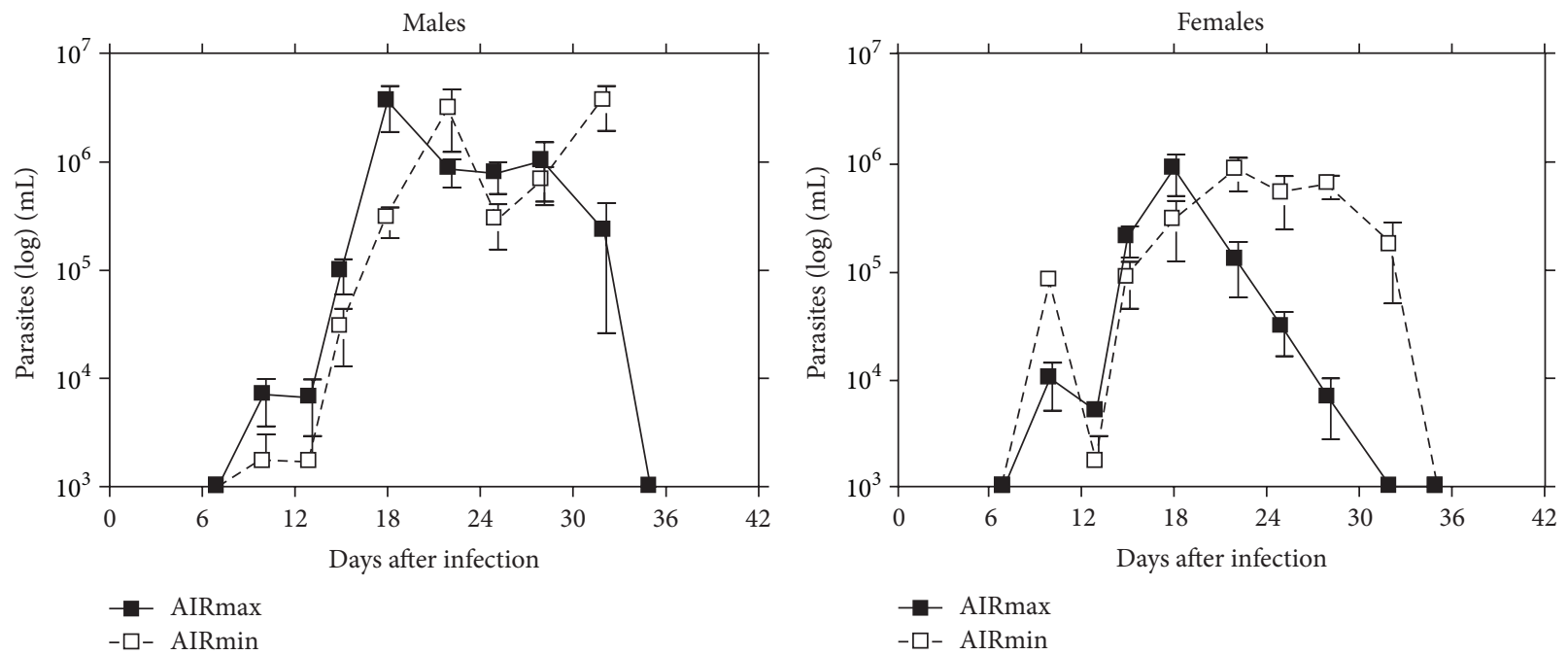

(a)
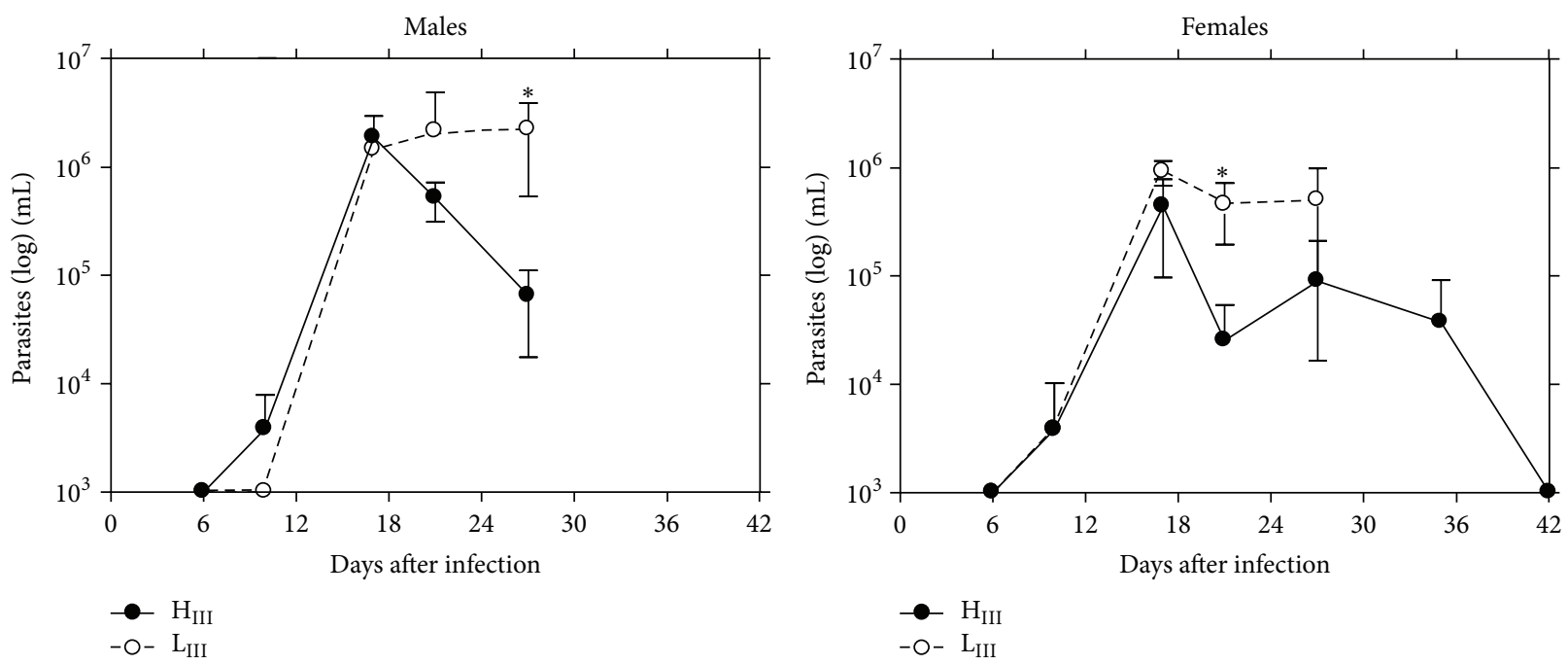

(b)

FIgURE 3: Parasitemia of (a) AIRmax, AIRmin mice ( $n=6$ animals/group), and (b) $\mathrm{H}_{\mathrm{II}}, \mathrm{L}_{\mathrm{III}}$ mice ( $n=4$ animals/group) during the acute phase of infection with $10^{2}$ trypomastigote forms of T. cruzi (CL strain). The results are expressed as the mean \pm SE of each group of males and females and significant differences between AIRmax versus AIRmin and between $\mathrm{H}_{\text {III }}$ versus $\mathrm{L}_{\text {III }}$ mouse lines in parasitemia levels are indicated: ${ }^{*} P<0.05$.

identical resistance patterns to T. cruzi challenges (data not shown), indicating that there were no maternal or parental effects in determining resistance/susceptibility to infection. On the other hand, there was an overdominance effect of the resistance phenotype, with F1 hybrids showing greater resistance than the parental $\mathrm{H}_{\mathrm{III}}$ line (Figures 6(a), 6(b), and 6(c)).

Due to the strong overdominance observed in F1 mice infected with $10^{2}$ parasites (Figure 6(c)) and to a wide range of other challenge doses (data not shown), a segregating population of 242 mice was constructed by backcrossing F1 mice with the susceptible parental $\mathrm{L}_{\mathrm{III}}$ line $(\mathrm{Bc}-\mathrm{L})$. Composite data related to the survival times of males and females from this backcross population (Figure 6(d)) were submitted to genetic analysis, considering sex as a covariate for that trait.
Of all microsatellites tested, the Ab QTL marker located at $34.8 \mathrm{cM}$ on chromosome 1 (D1Mit303) attained significant cosegregation values for survival time (Table 1). A more distal peak in chromosome 1 (marked by three adjacent microsatellites) also involved in Ab regulation in $\mathrm{H}_{\mathrm{III}}$ and $\mathrm{L}_{\text {III }}$ lines showed a suggestive level of cosegregation with mortality and survival rate.

\section{Discussion}

The present work demonstrated that polygenic regulation leading to high or low antibody production and maximal or minimal acute inflammatory responses affects host resistance against T. cruzi infections. Our results showed a positive 
TABLE 1: Significance of cosegregation between mortality and survival time traits with microsatellites markers of Ab regulating QTLs (quantitative trait loci) from Selection III or with candidate region markers of T. cruzi infection susceptibility.

\begin{tabular}{|c|c|c|c|c|c|}
\hline \multirow{2}{*}{\multicolumn{4}{|c|}{$\begin{array}{c}\text { Cosegregation test } \\
\text { Males and females Bc-L }\end{array}$}} & \multicolumn{2}{|c|}{ Trait } \\
\hline & & & & \multirow{2}{*}{$\begin{array}{c}\text { Mortality } \\
\text { LRS }^{\mathrm{c}}\end{array}$} & \multirow{2}{*}{$\begin{array}{c}\text { Survival time } \\
\text { LRS }^{\mathrm{d}}\end{array}$} \\
\hline Chrom. & Marker & $\begin{array}{ll} & \text { Location } \\
(\mathrm{Mb})^{\mathrm{a}} & \end{array}$ & $(\mathrm{cM})^{\mathrm{b}}$ & & \\
\hline \multirow{6}{*}{1} & D1Mit411 & $33220299-33220410$ & 12.6 & 1.6 & 1.6 \\
\hline & D1Mit303 & $62907596-62907723$ & 34.8 & 7.4 & $9.1^{\#}$ \\
\hline & D1Mit286 & $128551097-128551241$ & 67.0 & 3.4 & 3.9 \\
\hline & D1Mit102 & $147249520-147249632$ & 79.0 & 5.3 & 5.6 \\
\hline & D1Mit36 & $169211172-169211344$ & 92.3 & 3.9 & 5.6 \\
\hline & D1Mit149 & $172699229-172699330$ & 94.2 & 3.9 & 5.7 \\
\hline \multirow{2}{*}{3} & D3Mit272 & $33007369-33007465$ & 15.5 & 3 & 3.4 \\
\hline & D3Mit100 & 97081705-97081845 & 46.0 & 1.3 & 1.5 \\
\hline 5 & D5Mit122 & $150116320-150116477$ & 85.0 & 0 & 0 \\
\hline \multirow{3}{*}{6} & D6Mit123 & $\mathrm{N} / \mathrm{D}$ & 29.0 & 0.1 & 0.5 \\
\hline & D6Mit128 & $83471199-83471322$ & 35.0 & 0.2 & 0.1 \\
\hline & D6Mit6 & $85277319-85277417$ & 35.3 & 0.4 & 0.3 \\
\hline 7 & D7Mit176 & $63211190-63211340$ & 27.0 & 0.3 & 0.1 \\
\hline \multirow{3}{*}{9} & D9Mit90 & $32500455-32500594$ & 9.0 & 0.8 & 0.9 \\
\hline & D9Mit248 & $58362559-58362688$ & 31.0 & 0 & 0 \\
\hline & D9Mit207 & $60573431-60573577$ & 33.0 & 0.8 & 0.4 \\
\hline 11 & D11Mit4 & 68609257-68609504 & 37.0 & 0.2 & 0.9 \\
\hline 12 & D12Mit19 & $\mathrm{N} / \mathrm{D}$ & 58.0 & 1.3 & 1.1 \\
\hline 17 & D17Mit177 & $48558951-48559063$ & 24.0 & 1.8 & 1.1 \\
\hline
\end{tabular}

${ }^{a}$ Megabases (mouse genome database); ${ }^{\mathrm{b}}$ CentiMorgans (mouse genome database); ${ }^{\mathrm{c}}$ likelihood ratio statistic; ${ }^{\mathrm{d}}$ survival time (days); N/D: not determined. Critical LRS statistic values established by Random Permutation Test for the trait.

(i) Mortality: significant $\geq 8.8$; highly significant $\geq 15.5$; suggestive $\geq 2.7$.

(ii) Survival time: " significant $\geq 7.9$; highly significant $\geq 14$. ; suggestive $\geq 2.8$.
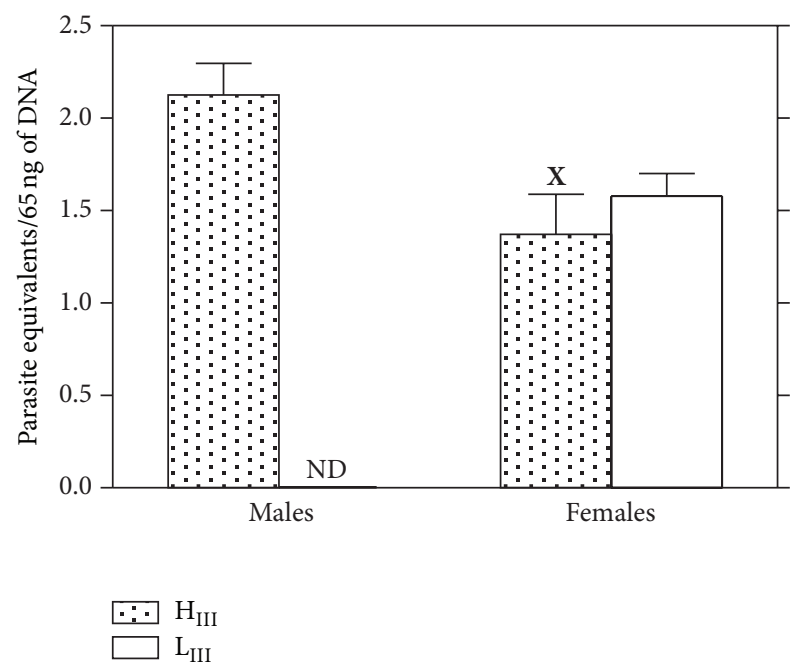

Figure 4: Parasite loads in the cardiac muscles of $\mathrm{H}_{\text {III }}$ and $\mathrm{L}_{\text {III }}$ male and female mice 150 days after infection (sc) with $10^{3}$ trypomastigote forms of the CL strain of T. cruzi. Significant differences of the parasite loads in $65 \mathrm{ng}$ of DNA isolated from cardiac tissue are indicated: ${ }^{\mathrm{x}_{P}}=0.0125$ (between $\mathrm{H}_{\mathrm{III}}$ males and $\mathrm{H}_{\mathrm{III}}$ females); ND: not determined (all male $\mathrm{L}_{\text {III }}$ mice die in the acute phase). correlation between the resistance phenotype and mouse lines selected for high responses.

During acute infection, mice from both high-responder lines had lower mortality rates and showed greater capacities to control circulating parasites when compared to lowresponder animals. This correlation was more evident among female mice.

Gender differences were also observed in mortality rates, with male mice being more susceptible than females. Male mice have been observed to be more susceptible to acute infections than females in other genetic mouse models, with significantly lower numbers of circulating parasites being observed in the latter [48], and hormones such as estrogen have been observed to reduce mortality in T. cruzi infected mice, presumably by their ability to stimulate macrophage activity [49]. Using Calomys callosus as an experimental model, Prado Jr. et al. [50, 51] showed that gonadectomy affected the courses of T. cruzi infections in females, with high parasitemia levels in the ovariectomized animals as compared to controls and sham-operated groups, indicating that sex hormones can influence natural immune mechanisms. The influence of gender on human susceptibility to T. cruzi has similarly been reported $[52,53]$. 

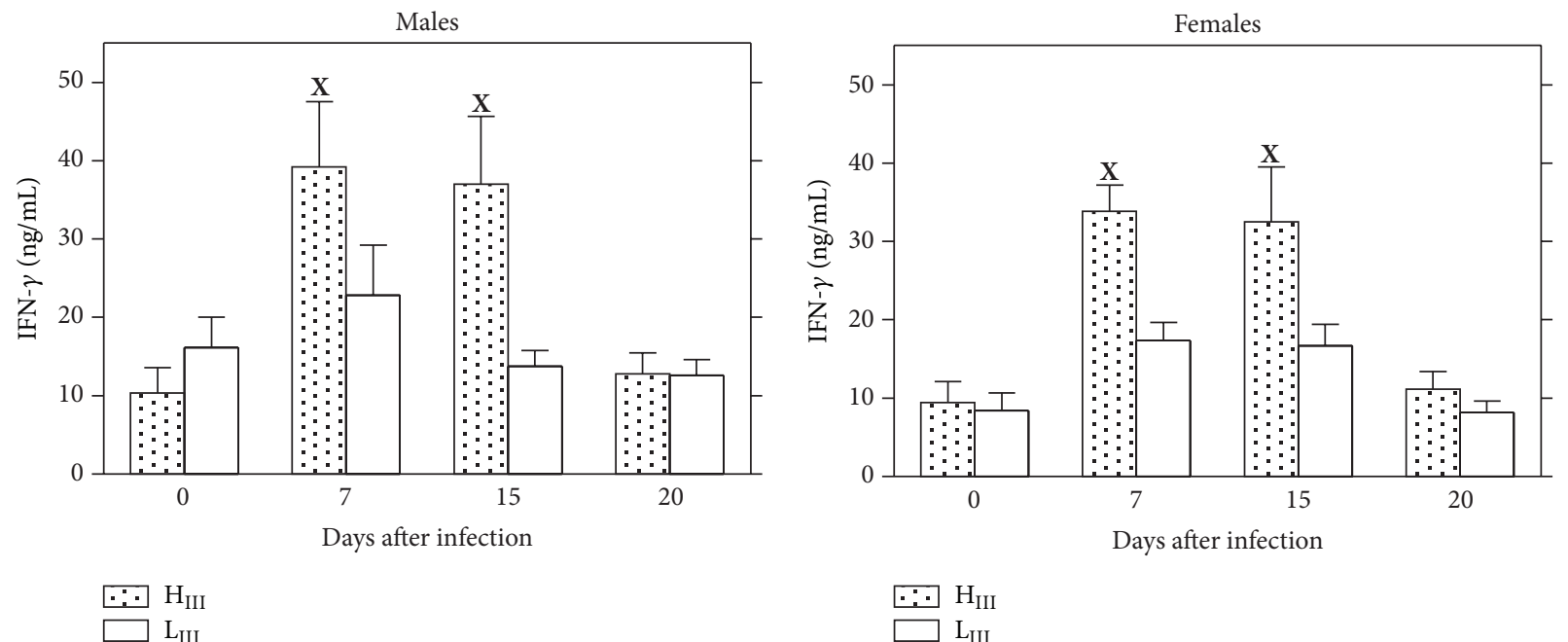

(a)
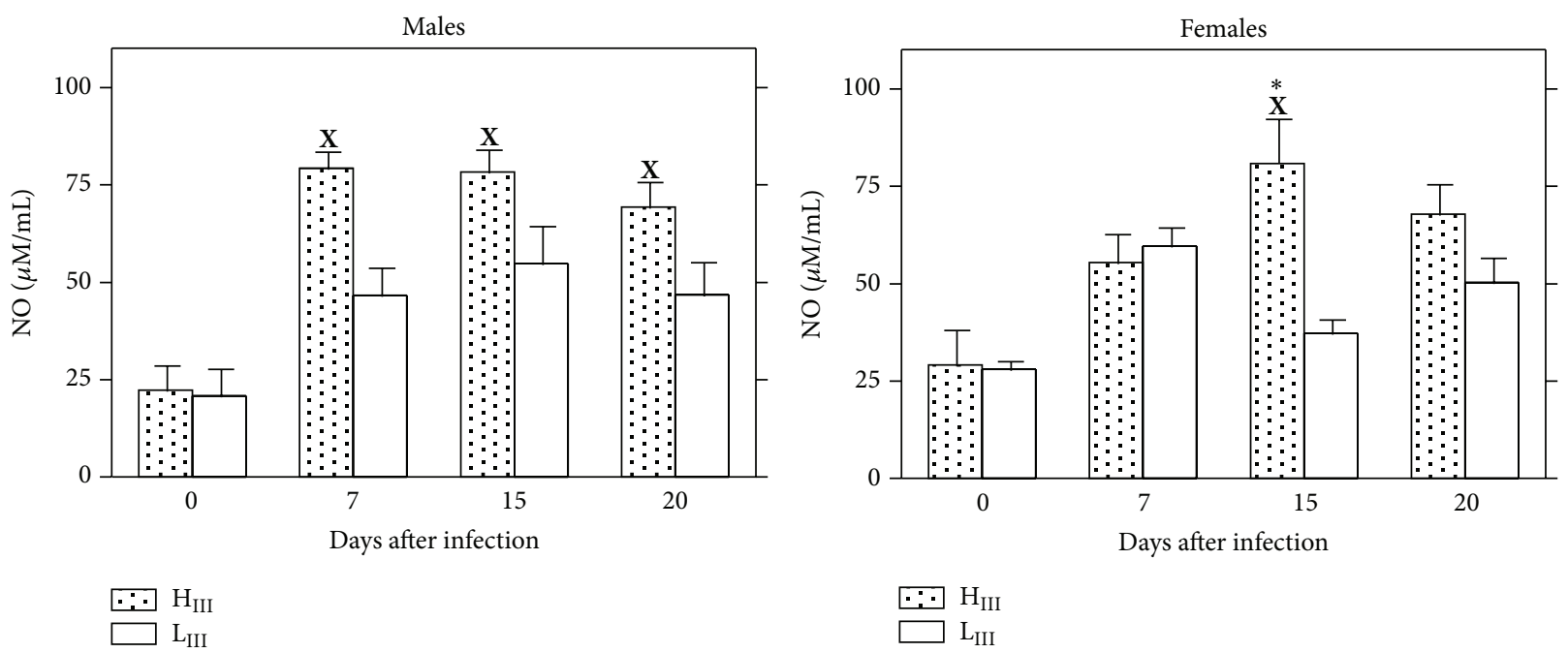

(b)

FIGURE 5: IFN- $\gamma$ (a) and nitric oxide (NO) (b) production by lymph node (a) and peritoneal cells (b) during the acute phase of infection with $10^{2}$ T. cruzi parasites (CL strain) in outbred $\mathrm{H}_{\mathrm{III}}$ and $\mathrm{L}_{\mathrm{III}}$ mice. Cells were stimulated in culture with ConA $(2.5 \mu \mathrm{g} / \mathrm{mL})$ for $48 \mathrm{~h}$. Results are expressed as the means \pm SE of each group $(n=6)$. Significant differences between infected and control mice $(\mathbf{X})$ or between lines $(*)$ evaluated by ANOVA followed by Tukey multiple comparison tests are indicated when $P<0.05$.

Recent work analyzing an F2 population obtained by intercrossing resistant and susceptible isogenic strains of mice found a significant association between parasitemia and mortality. By analyzing males and females separately, the authors found that males were more susceptible to death but parasitemia was similar in males and females. In fact they obtained a negative correlation of parasitemia with longevity in females but not in males, suggesting that additional factors independent of parasitemia cause early mortality in males during infection with T. cruzi [54].

In the present study, the selected mouse lines behaved like other mouse lines with susceptible male mice dying with higher numbers of blood trypomastigotes, while in females this association could not be done. The resistant mice enter the chronic phase without detectable parasites in their bloodstreams.

Some studies demonstrated that antibodies are responsible for the survival of susceptible animals in the initial phase of T. cruzi infection and for the maintenance of low levels of parasitemia in the chronic phase [55-57]. Despite the important effector role of antibody in the control of T. cruzi infection, resistant lines do not necessarily produce higher levels of specific antibody in comparison to susceptible lines $[58,59]$. Elevation of specific antibody in the acute phase T. cruzi infection showed no correlation with the survival in isogenic mice. In the other hand, resistance correlated with enhance of some parasite-specific antibodies isotypes, particularly of IgG2b, [60-62]. 


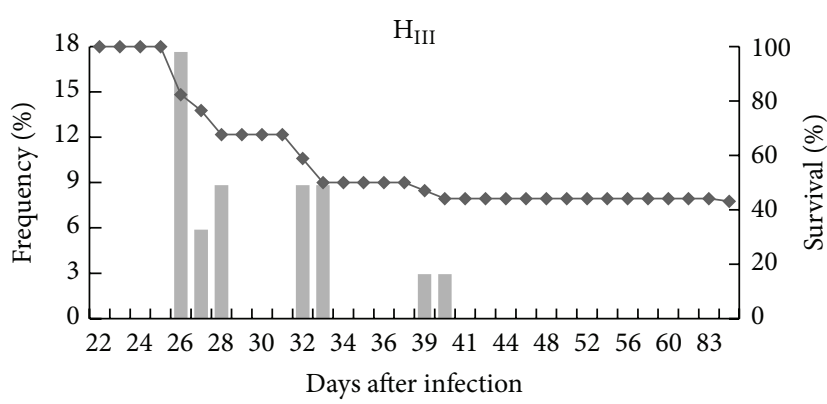

(a)

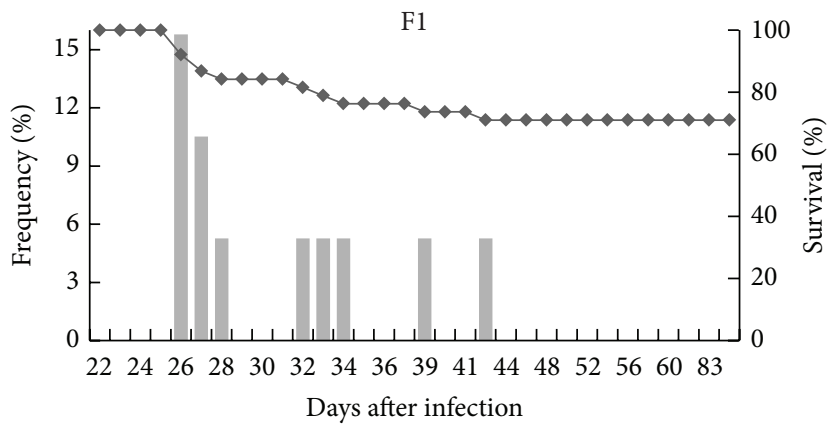

(c)

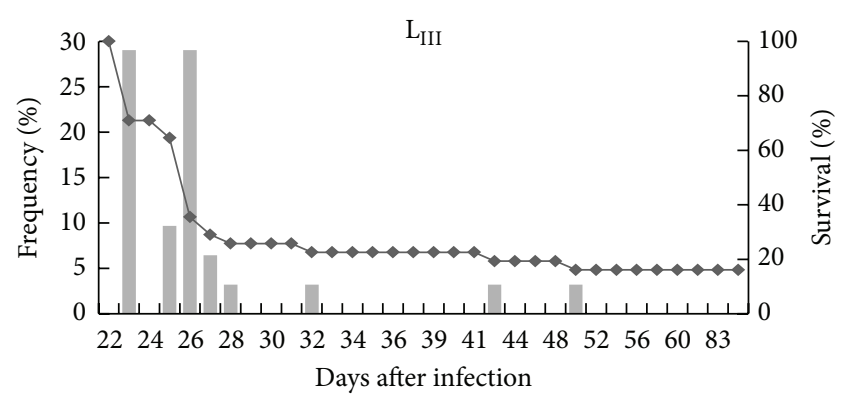

(b)

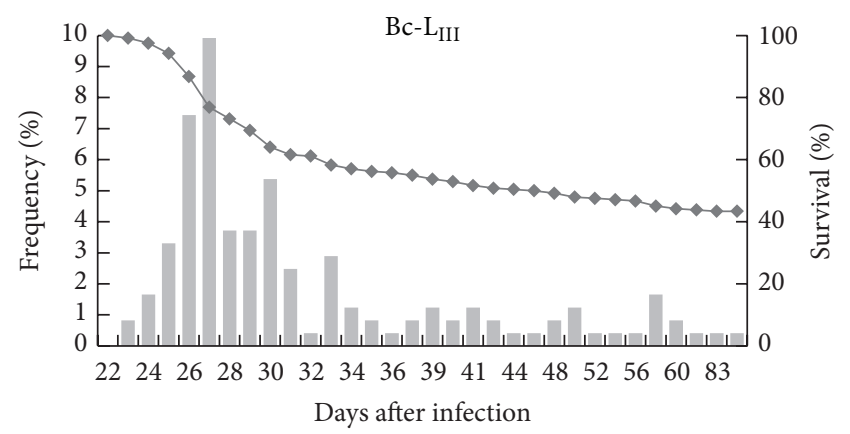

(d)

FIgURE 6: Survival curves and the mortality frequencies each day after T. cruzi infection. Males and females of inbred parental $\mathrm{H}_{\mathrm{III}}(\mathrm{a})$ and $\mathrm{L}_{\text {III }}$ (b) lines, F1 $\left(\mathrm{H}_{\text {III }} \times \mathrm{L}_{\text {III }}\right)$ hybrids $(\mathrm{c})$, and backcrossed Bc-L $\left(\mathrm{F} 1 \times \mathrm{L}_{\text {III }}\right)$ mice populations $(\mathrm{d})$. Mice were infected (s.c.) with $10^{3}$ blood forms of the CL strain of T. cruzi and monitored daily for mortality.

It has been shown that an X-linked mutation (that prevents B1 cell development and specific and nonspecific immunoglobulins production) of Balb. Xid immunodeficient mice influences resistance to infection. Surprisingly, T. cruzi infected Xid mice were more resistant than wild-type mice, and the resistance was associated with the absence of IL-10 secreting $B 1$ cells and increased production of IFN- $\gamma[63,64]$.

Cellular immune responses are considered important components of resistance to T. cruzi infection, with IFN- $\gamma$ as a central mediator that activates NO-dependent parasiticidal mechanisms in macrophages $[17,65,66]$.

In the present study, the increased levels of IFN- $\gamma$ observed 7 and 15 days after infection in ConA-stimulated cells from $\mathrm{H}_{\mathrm{III}}$ mice (Figure 5(a)) (as compared to cells from $\mathrm{L}_{\text {III }}$ mice) apparently trigger the higher NO levels observed in stimulated cells in those animals, suggesting an association between NO production and infection resistance. However, $\mathrm{NO}$ and IFN- $\gamma$ were produced in significant levels in both resistant female and susceptible male mice of the $\mathrm{H}_{\text {III }}$ and AIRmax and AIRmin lines, indicating that IFN- $\gamma$ and NO secretion are not the only parameters that contribute to gender differences in infection resistance and may not always correlate with survival, so that other mechanisms must be involved.

Wrightsman et al. [25] studied the genetic control of responses to $T$. cruzi infection and observed that multiple genes were involved in the control of parasitemia and survival, with female F1 hybrid mice from crosses of several susceptible and resistant mouse lines surviving the infections, indicating dominance of the resistance genes. Our results confirmed and extended these observations, indicating an overdominance of the resistance phenotype in $\mathrm{Fl}\left(\mathrm{H}_{\mathrm{III}} \times \mathrm{L}_{\mathrm{III}}\right)$ mice, with females being more resistant than males.

This data is in agreement with other genetic studies in which infection resistance was observed to be inherited in a dominant manner, with heterozygosity in crosses between susceptible and resistant inbred lines (or even between two susceptible lines) increasing resistance [24-26, 67]. Overall, these results indicate that, in addition to polygenic regulation, there is complementarity between different loci in determining the infection resistance phenotype.

The overdominance of the resistance phenotype in Selection III mouse lines led us to choose a segregating population Bc-L, created by backcrossing F1 $\left[\mathrm{H}_{\mathrm{III}} \times \mathrm{L}_{\mathrm{III}}\right]$ with the susceptible parental $\mathrm{L}_{\mathrm{III}}$ mice, to carry out the genetic linkage analysis. Backcrosses are more powerful than intercrosses for examining dominant/recessive traits because they eliminate interference from homozygous dominant genotypes in the analyses [68].

Susceptibility to infectious disease is influenced by multiple host genes, most of which are low penetrance QTLs that are difficult to map. So, the strategy that we chose for genetic analysis was to analyze the linkage between the mortality and survival phenotypes after infection of the $\mathrm{Bc}-\mathrm{L}$ population with markers that were previously described as implicated in antibody production regulation as well as other markers implicated in resistance to T. cruzi infection

Microsatellite markers of QTLs for antibody production mapping on chromosomes $1,3,5,6,9,11$, and 12 were tested in this linkage analysis [30]. We also genotyped polymorphic 
microsatellites among lines of Selection III mice that mark chromosomal regions related to resistance to acute infection by $T$. cruzi on chromosome 7 and near the H-2 locus on murine chromosome 17 [67, 69]. Two other markers on chromosome 1 were tested in a region associated with resistance to African trypanosomiasis (Tir3b) [70].

We detected a significant association between alleles of an Ab QTL on chromosome 1 (marked by microsatellite D1Mit303 at $34.8 \mathrm{cM}$ ) with the survival phenotype after $T$. cruzi acute infection, obtaining a significant level of cosegregation in this region in spite of the strong influences on the phenotype of environmental factors such as sex hormones and limited population sizes.

Iraqi et al. [70] described one QTL (Tir3a) associated with African trypanosomiasis infection adjacent to the abovementioned QTL confidence interval. This region overlaps a QTL that controls antibody production in $\mathrm{H}_{\mathrm{III}}$ and $\mathrm{L}_{\mathrm{III}}$ mouse lines as well as a putative QTL for acute inflammatory response mapped in AIRmax and AIRmin mice [71]. Several genes map at the QTL interval that could interfere in the various steps of innate or adaptative immune response regulation.

A candidate gene in this region is Slc1lal (solute carrier family 11; proton-coupled divalent metal ion transporters, member 1 (formerly known as Nrampl)) which is a major gene regulating control of intracellular pathogen infections such as those caused by Salmonella Typhimurium, Leishmania donovani, and Mycobacterium bovis bacillus CalmetteGuerin (BCG) in mice and humans. This gene is also involved in inflammatory autoimmune diseases [72] and seems to interact with other genes to modulate this phenotype [73], as could be the case with T. cruzi infection in mice selected for acute inflammatory reaction.

However, this gene has no influence on the differential response of Selection III mice to T. cruzi because both lines have the resistance associated allele of this gene [74]. Despite this, $\mathrm{H}_{\mathrm{III}}$ and $\mathrm{L}_{\mathrm{III}}$ lines differ in susceptibility to Salmonella Typhimurium showing that the region that controls antibody production marked by the D1Mit303 microsatellite harbor genes involved in resistance to this bacterial infection [74] and also to T. cruzi, in absence of Nrampl polymorphism. Also in humans a lack of association between NRAMP1 gene polymorphism and T. cruzi infection was described [75].

Other genes located in this region, such as Casp8, Icos (induced T-cell costimulator), CD28, and chemokine receptors Cxcr1 and Cxcr2 (IL-8 receptor) could also be involved in this phenotype by regulating activation of the inflammatory and adaptive immune responses.

Genes evolved in apoptosis like Casp 8 may be implicated in the different resistance pattern we observed. Infection with T. cruzi triggers apoptosis of T and B lymphocytes, and lymphocyte apoptosis has immunoregulatory implications for host immune responses [22]. Treatment in vivo with a caspase inhibitor reduces lymphocyte apoptosis and improves protective immune responses in mice infected with T. cruzi [76].

Other studies assessed the involvement of caspase signaling in thymocyte death during T. cruzi infection and showed that caspase- 8 and caspase- 9 mediate thymocyte apoptosis in Trypanosoma cruzi acutely infected mice [77].
Another gene described in this region codes for CD28 molecule that mediates costimulatory signals required for $\mathrm{T}$ cell activation. The involvement of CD28 in the modulation of protective immunity against $T$. cruzi was shown by mediating the activation of both CD4+ and CD8+ T cells, the production of IFN- $\gamma$, and, as a consequence, the production of NO efficient to control parasite growth during the acute phase of the infection. Mice knockout for CD28 presented high parasitemia and mortality [78]. However, when infected with the low virulent Sylvio X10/4 trypanosome strain CD28KO mice exhibited resistant phenotype, with no parasitemia or mortality [79].

Chagasic patients lack CD28 expression on many of their circulating T lymphocytes [80].

The role of CXC chemokines in proinflammatory phenotype, developed by T. cruzi infection, was shown by experiments, in which tissue culture trypomastigotes activate innate sentinel cells via TLR2, releasing CXC chemokines, which in turn evoke neutrophil/CXCR2-dependent extravasation of plasma proteins, including high molecular weight kininogen, in parasite infected tissues $[81,82]$.

The QTL on chromosomes 3 and 9 that show the highest cosegregation significance with antibody production levels in $\mathrm{H}_{\mathrm{III}}$ and $\mathrm{L}_{\mathrm{III}}$ mice [30] were not involved in T. cruzi infection control. In previous studies with parasite infections, the response of Selection III lines to infection by the protozoan Toxoplasma gondii showed correlation with the potentiality of specific antibody production of their lines [83]. Also in the course of infection by $\mathrm{Y}$ strain of $T$. cruzi, minor mortality rates and more efficient control of parasitemia were associated with significant differences in T. cruzi specific IgG antibodies [84]. Herein, using CL strain, we quantified antibodies against T. cruzi antigen during the acute phase of infection but no differences in specific antibody production could be detected between lines, in spite of an increase of both IgM and IgG levels at 20 days of infection (data not shown), presumably due to a polyclonal activation induced by this parasite $[85,86]$.

The chromosome $5 \mathrm{Ab}$ QTL located at $85 \mathrm{cM}$ was not associated with the phenotypes analyzed here, although Graefe et al. $[67,87]$ described a locus on chromosome 5 at $58 \mathrm{cM}$ associated with male mortality in the acute phase of T. cruzi Tulahuen strain infection [87]. Iraqi et al. [70] also described a QTL associated with survival of $T$. congolense infections adjacent to this region (at 42-44 cM). One reason for the failure to detect any association may be the large genetic distance between the marker and the published $T$. cruzi resistance QTL on this chromosome. The markers available in this $40-60 \mathrm{cM}$ interval in the microsatellite panel used for mapping Ab QTL were not polymorphic among the $\mathrm{H}_{\mathrm{III}}$ and $\mathrm{L}_{\mathrm{III}}$ lines, and additional markers will need to be tested for polymorphism and any associations before definitive conclusions can be drawn.

The chromosome 11 QTL showed the highest significance among the resistance loci (survival) to the $\mathrm{Y}$ strain parasite in inbred mice [67]. These and other authors also described a QTL on chromosome 17 close to the H-2 complex as a determinant of responses to challenge with both $T$. congolense (Tir1) [70] and T. cruzi [66], although this region was not 
associated with either T. cruzi infection control or antibody production phenotypes in $\mathrm{H}_{\mathrm{III}}$ and $\mathrm{L}_{\mathrm{III}}$ mouse lines in the present study $[30,88]$.

Differential gene expression was analyzed in the spleens of infected susceptible C57BL/6 and resistant (C57BL/6 X $\mathrm{DBA} / 2$ ) F1 mice using microarrays, and the results suggested that the differential transcription of certain genes involved in immune responses and inflammatory processes accounted for the differences in susceptibility to the Tulahuen strain of T. cruzi [87].

In humans many genetic linkages and association studies have attempted to identify genetic variations that are involved in immunopathogenesis of Chagas disease. However, causal genetic variants underlying susceptibility remain unknown due to complexity of parasite and host. Susceptibility/resistance to Chagas disease involves multiple genetic variants functioning jointly, each with small or moderate effects [89]. Polymorphism in the ACTC1 gene of humans contributes to the progression to chronic autoimmune Chagas cardiomyopathy [90], and polymorphisms of other genes that affect several immune parameters such as innate immunity, signal transduction, and T-cell/monocyte migration to inflammatory regions play a role in genetic susceptibility to CCC development [91].

Our data suggest that one out of the several quantitative trait loci that regulate antibody production also contributes to the control of T.cruzi infection. Multiple genes control the several steps of antibody synthesis or of infection. The modifications in mechanisms that lead to differential immune response of $\mathrm{H}_{\mathrm{III}}$ and $\mathrm{L}_{\mathrm{III}}$ selected lines rather than the produced anti-T.cruzi antibodies might play a major role in infection outcome.

Overall, the results of this study demonstrated that an immunomodulatory QTL mapping on mouse chromosome 1 significantly cosegregated with the phenotype of survival time to acute T. cruzi infection. Therefore, our data indicates that a region controlling $\mathrm{Ab}$ production and inflammation on mouse chromosome 1 harbors genetic factors that also determine resistance to acute T. cruzi infections. This region had not previously been implicated with this disease, demonstrating the potential of this genetic model for dissecting complex multigenic regulated traits.

\section{Conflict of Interests}

The authors declare that there is no conflict of interests regarding the publication of this paper.

\section{Acknowledgments}

This work was supported by Fundação de Amparo à Pesquisa do Estado de São Paulo (FAPESP); Marcelo De Franco and Olga M. Ibañez were supported in part by Conselho Nacional de Pesquisas (CNPq).

\section{References}

[1] L. Hudson, "Immunobiology of Trypanosoma cruzi infection and Chagas' disease," Transactions of the Royal Society of Tropical Medicine and Hygiene, vol. 75, no. 4, pp. 493-498, 1981.
[2] R. T. Gazzinelli and E. Y. Denkers, "Protozoan encounters with Toll-like receptor signalling pathways: implications for host parasitism," Nature Reviews Immunology, vol. 6, no. 12, pp. 895906, 2006.

[3] A. C. Oliveira, J. R. Peixoto, L. B. de Arrada et al., "Expression of functional TLR4 confers proinflammatory responsiveness to Trypanosoma cruzi glycoinositolphospholipids and higher resistance to infection with T. cruzi," The Journal of Immunology, vol. 173, no. 9, pp. 5688-5696, 2004.

[4] C. Ropert, L. R. P. Ferreira, M. A. S. Campos et al., "Macrophage signaling by glycosylphosphatidylinositol-anchored mucin-like glycoproteins derived from Trypanosoma cruzi trypomastigotes," Microbes and Infection, vol. 4, no. 9, pp. 1015-1025, 2002.

[5] I. C. Almeida, M. M. Camargo, D. O. Procópio et al., "Highly purified glycosylphosphatidylinositols from Trypanosoma cruzi are potent proinflammatory agents," EMBO Journal, vol. 19, no. 7, pp. 1476-1485, 2000.

[6] M. A. S. Campos, I. C. Almeida, O. Takeuchi et al., "Activation of toll-like receptor-2 by glycosylphosphatidylinositol anchors from a protozoan parasite," Journal of Immunology, vol. 167, no. 1, pp. 416-423, 2001.

[7] A. Bafica, H. C. Santiago, R. Goldszmid, C. Ropert, R. T. Gazzinelli, and A. Sher, "Cutting edge: TLR9 and TLR2 signaling together account for MyD88-dependent control of parasitemia in Trypanosoma cruzi infection," Journal of Immunology, vol. 177, no. 6, pp. 3515-3519, 2006.

[8] B. C. Caetano, B. B. Carmo, M. B. Melo et al., "Requirement of UNC93B1 reveals a critical role for TLR7 in host resistance to primary infection with Trypanosoma cruzi," The Journal of Immunology, vol. 187, no. 4, pp. 1903-1911, 2011.

[9] M. M. Rodrigues, A. C. Oliveira, and M. Bellio, "The immune response to Trypanosoma cruzi: role of toll-like receptors and perspectives for vaccine development," Journal of Parasitology Research, vol. 2012, Article ID 507874, 12 pages, 2012.

[10] G. K. Silva, F. R. S. Gutierrez, P. M. M. Guedes et al., “Cutting edge: nucleotide-binding oligomerization domain 1-dependent responses account for murine resistance against Trypanosoma cruzi infection," The Journal of Immunology, vol. 184, no. 3, pp. 1148-1152, 2010.

[11] GK. Silva, RS. Costa, TN. Silveira et al., "Apoptosis-associated speck-like protein containing a caspase recruitment domain inflammasomes mediate IL- $\beta$ response and host resistance to Trypanosoma cruzi infection," The Journal of Immunology, vol. 191, pp. 3373-3383, 2013.

[12] V. M. Gonçalves, K. C. Matteucci, C. L. Buzzo et al., "NLRP3 controls Trypanosoma cruzi infection through a caspase-1dependent IL-1R-independent NO production," PLoS Neglected Tropical Diseases, vol. 7, no. 10, Article ID e2469, 2013.

[13] C. A. Hunter, T. Slifer, and F. Araujo, "Interleukin-12-mediated resistance to Trypanosoma cruzi is dependent on tumor necrosis factor alpha and gamma interferon," Infection and Immunity, vol. 64, no. 7, pp. 2381-2386, 1996.

[14] J. C. S. Aliberti, M. A. G. Cardoso, G. A. Martins, R. T. Gazzinelli, L. Q. Vieira, and J. S. Silva, "Interleukin-12 mediates resistance to Trypanosoma cruzi in mice and is produced by murine macrophages in response to live trypomastigotes," Infection and Immunity, vol. 64, no. 6, pp. 1961-1967, 1996.

[15] F. Cardillo, J. C. Voltarelli, S. G. Reed, and J. S. Silva, "Regulation of Trypanosoma cruzi infection in mice by gamma interferon and interleukin 10: role of NK cells," Infection and Immunity, vol. 64, no. 1, pp. 128-134, 1996. 
[16] J. S. Silva, G. N. R. Vespa, M. A. G. Cardoso, J. C. S. Aliberti, and F. Q. Cunha, "Tumor necrosis factor alpha mediates resistance to Trypanosoma cruzi infection in mice by inducing nitric oxide production in infected gamma interferon-activated macrophages," Infection and Immunity, vol. 63, no. 12, pp. 48624867, 1995.

[17] G. N. R. Vespa, F. Q. Cunha, and J. S. Silva, "Nitric oxide is involved in control of Trypanosoma cruzi-induced parasitemia and directly kills the parasite in vitro," Infection and Immunity, vol. 62, no. 11, pp. 5177-5182, 1994.

[18] J. S. Silva, F. S. Machado, and G. A. Martins, "The role of nitric oxide in the pathogenesis of chagas disease," Frontiers in Bioscience, vol. 8, pp. s314-s325, 2003.

[19] M. Russo, N. Starobinas, P. Minoprio, A. Coutinho, and M. Hontebeyrie-Joskowicz, "Parasitic load increases and myocardial inflammation decreases in Trypanosoma cruzi-infected mice after inactivation of helper T cells," Annales de l'Institut Pasteur/Immunologie, vol. 139, pp. 225-236, 1988.

[20] R. L. Tarleton, B. H. Koller, A. Latour, and M. Postan, "Susceptibility of $\beta 2$-microglobulin-deficient mice to Trypanosoma cruzi infection," Nature, vol. 356, no. 6367, pp. 338-340, 1992.

[21] M. E. Rottenberg, A. Riarte, L. Sporrong et al., "Outcome of infection with different strains of Trypanosoma cruzi in mice lacking CD4 and/or CD8," Immunology Letters, vol. 45, no. 1-2, pp. 53-60, 1995.

[22] G. A. DosReis, "Evasion of immune responses by Trypanosoma cruzi, the etiological agent of Chagas disease," Brazilian Journal of Medical and Biological Research, vol. 44, no. 2, pp. 84-90, 2011.

[23] T. Trischmann, H. Tanowitz, M. Wittner, and B. Bloom, "Trypanosoma cruzi: role of the immune response in the natural resistance of inbred strains of mice," Experimental Parasitology, vol. 45, no. 2, pp. 160-168, 1978.

[24] T. M. Trischmann and B. R. Bloom, "Genetics of murine resistance to Trypanosoma cruzi," Infection and Immunity, vol. 35 , no. 2, pp. 546-551, 1982.

[25] R. Wrightsman, S. Krassner, and J. Watson, "Genetic control of responses to Trypanosoma cruzi in mice: multiple genes influencing parasitemia and survival," Infection and Immunity, vol. 36, no. 2, pp. 637-644, 1982.

[26] G. K. Silva, L. D. Cunha, C. V. Horta et al., "A parent-of-origin effect determines the susceptibility of a non-informative F1 population to Trypanosoma cruzi infection in vivo," PLoS ONE, vol. 8, no. 2, Article ID e56347, pp. 1-10, 2013.

[27] M. Siqueira, A. Bandieri, M. S. Reis, O. A. Sant’anna, and G. Biozzi, "Selective breeding of mice for antibody responsiveness to flagellar and somatic antigens of Salmonellae," European Journal of Immunology, vol. 6, no. 4, pp. 241-249, 1976.

[28] M. Siqueira, M. B. Esteves, O. M. Ibanez et al., "Nonspecific genetic regulation of antibody responsiveness in the mouse," European Journal of Immunology, vol. 7, no. 4, pp. 195-203, 1977.

[29] G. Biozzi, D. Mouton, O. A. Sant'Anna et al., "Genetics of immunoresponsiveness to natural antigens in the mouse," Current Topics in Microbiology and Immunology, vol. 85, pp. 3198, 1979.

[30] C. M. de Souza, L. Morel, W. H. K. Cabrera et al., "Quantitative trait loci in Chromosomes 3, 8, and 9 regulate antibody production against Salmonella flagellar antigens in the mouse," Mammalian Genome, vol. 15, no. 8, pp. 630-636, 2004.

[31] O. M. Ibañez, D. Mouton, O. G. Ribeiro et al., "Low antibody responsiveness is found to be associated with resistance to chemical skin tumorigenesis in several lines of Biozzi mice," Cancer Letters, vol. 136, no. 2, pp. 153-158, 1999.
[32] J. R. Jensen, L. C. Peters, A. Borrego et al., "Involvement of antibody production quantitative trait loci in the susceptibility to pristane-induced arthritis in the mouse," Genes and Immunity, vol. 7, no. 1, pp. 44-50, 2006.

[33] C. Stiffel, O. M. Ibanez, O. G. Ribeiro et al., "Genetic regulation of the specific and non-specific component of immunity," Immunology Letters, vol. 16, no. 3-4, pp. 205-217, 1987.

[34] C. Stiffel, O. M. Ibanez, O. G. Ribeiro et al., "Genetics of acute inflammation: inflammatory reactions in inbred lines of mice and in their interline crosses," Experimental and Clinical Immunogenetics, vol. 7, no. 4, pp. 221-233, 1990.

[35] O. M. Ibanez, C. Stiffel, O. G. Ribeiro et al., "Genetics of nonspecific immunity: I. Bidirectional selective breeding of lines of mice endowed with maximal or minimal inflammatory responsiveness," European Journal of Immunology, vol. 22, no. 10, pp. 2555-2563, 1992.

[36] G. Biozzi, O. G. Ribeiro, A. Saran et al., "Effect of genetic modification of acute inflammatory responsiveness on tumorigenesis in the mouse," Carcinogenesis, vol. 19, no. 2, pp. 337-346, 1998.

[37] N. D. Vigar, W. H. Cabrera, L. M. Araujo et al., "Pristaneinduced arthritis in mice selected for maximal or minimal acute inflammatory reaction," European Journal of Immunology, vol. 30, pp. 431-437, 2000.

[38] L. M. M. Araujo, O. G. Ribeiro, M. Siqueira et al., "Innate resistance to infection by intracellular bacterial pathogens differs in mice selected for maximal or minimal acute inflammatory response," European Journal of Immunology, vol. 28, pp. 29132920, 1998.

[39] D. A. Maria, G. Manenti, F. Galbiati et al., "Pulmonary adenoma susceptibility 1 (Pas1) locus affects inflammatory response," Oncogene, vol. 22, no. 3, pp. 426-432, 2003.

[40] J. R. Jensen, A. Galvan, A. Borrego et al., "Genetic control of renal tumorigenesis by the mouse Rtm1 locus," BMC Genomics, vol. 14, article 724, 2013.

[41] R. F. Di Pace, S. Massa, O. G. Ribeiro et al., "Inverse genetic predisposition to colon versus lung carcinogenesis in mouse lines selected based on acute inflammatory responsiveness," Carcinogenesis, vol. 27, no. 8, pp. 1517-1525, 2006.

[42] M. de Franco, P. D. S. Carneiro, L. C. Peters et al., "Slcllal (Nramp1) alleles interact with acute inflammation loci to modulate wound-healing traits in mice," Mammalian Genome, vol. 18, no. 4, pp. 263-269, 2007.

[43] K. L. Cummings and R. L. Tarleton, "Rapid quantitation of Trypanosoma cruzi in host tissue by real-time PCR," Molecular and Biochemical Parasitology, vol. 129, no. 1, pp. 53-59, 2003.

[44] K. F. Manly and J. M. Olson, "Overview of QTL mapping software and introduction to map manager QT," Mammalian Genome, vol. 10, no. 4, pp. 327-334, 1999.

[45] K. F. Manly, R. H. Cudmore Jr., and J. M. Meer, "Map Manager QTX, cross-platform software for genetic mapping," Mammalian Genome, vol. 12, no. 12, pp. 930-932, 2001.

[46] E. Lander and L. Kruglyak, "Genetic dissection of complex traits: guidelines for interpreting and reporting linkage results," Nature Genetics, vol. 11, no. 3, pp. 241-247, 1995.

[47] G. A. Churchill and R. W. Doerge, "Empirical threshold values for quantitative trait mapping," Genetics, vol. 138, no. 3, pp. 963971, 1994.

[48] W. L. Chapman Jr., W. L. Hanson, and V. B. Waits, “The influence of gonadectomy of host on parasitemia and mortality of mice infected with Trypanosoma cruzi," Journal of Parasitology, vol. 61, no. 2, pp. 213-216, 1975. 
[49] F. Kierszenbaum, E. Knecht, D. B. Budzko, and M. C. Pizzimenti, "Phagocytosis: a defense mechanism against infection with Trypanosoma cruzi," Journal of Immunology, vol. 112, no. 5, pp. 1839-1844, 1974.

[50] J. Prado Jr., M. P. Leal, J. A. Anselmo-Franci, H. F. Andrade Jr., and J. K. Kloetzel, "Influence of female gonadal hormones on the parasitemia of female Calomys collosus infected with the "Y" strain of Trypanosoma cruz," Parasitology Research, vol. 84, pp. 100-105, 1998.

[51] Jr. do Prado J. C., A. M. A. de Levy, M. de Paula Leal, E. Bernard, and J. K. Kloetzel, "Influence of male gonadal hormones on the parasitemia and humoral response of male Calomys callusus infected with the Y strain of Trypanosoma cruzi," Parasitology Research, vol. 85, no. 10, pp. 826-829, 1999.

[52] A. C. Barretto, E. Arteaga, C. Mady, B. M. Ianni, G. Bellotti, and F. Pileggi, "Male sex. Prognostic factor in Chagas' disease," Arquivos Brasileiros de Cardiologia, vol. 60, no. 4, pp. 225-227, 1993.

[53] R. Espinosa, H. A. Carrasco, F. Belandria et al., "Life expectancy analysis in patients with Chagas' disease: prognosis after one decade (1973-1983)," International Journal of Cardiology, vol. 8, no. 1, pp. 45-56, 1985.

[54] T. L. M. Sanches, L. D. Cunha, G. K. Silva, P. M. M. Guedes, J. S. Silva, and D. S. Zamboni, "The use of a heterogeneously controlled mouse population reveals a significant correlation of acute phase parasitemia with mortality in Chagas disease," PLoS ONE, vol. 9, no. 3, Article ID e91640, 2014.

[55] L. F. Umekita, H. A. Takehara, and I. Mota, "Role of the antibody Fc in the immune clearance of Trypanosoma cruzi," Immunology Letters, vol. 17, no. 1, pp. 85-89, 1988.

[56] D. A. Bermejo, M. C. A. Vesely, M. Khan et al., “Trypanosoma cruzi infection induces a massive extrafollicular and follicular splenic B-cell response which is a high source of non-parasitespecific antibodies," Immunology, vol. 132, no. 1, pp. 123-133, 2011.

[57] M. C. A. Vesely, D. A. Bermejo, C. L. Montes, E. V. AcostaRodríguez, and A. Gruppi, "B-cell response during protozoan parasite infections," Journal of Parasitology Research, vol. 2012, Article ID 362131, 8 pages, 2012.

[58] E. N. de Gaspari, E. S. Umezawa, B. Zingales, A. M. Stolf, W. Colli, and I. A. Abrahamsohn, "Trypanosoma cruzi: serum antibody reactivity to the parasite antigens in susceptible and resistant mice.", Memorias do Instituto Oswaldo Cruz, vol. 85, no. 3, pp. 261-270, 1990.

[59] T. M. Trischmann, "Non-antibody-mediated control of parasitemia in acute experimental Chagas' disease," Journal of Immunology, vol. 130, no. 4, pp. 1953-1957, 1983.

[60] C. I. Brodskyn, A. M. M. Silva, H. A. Takehara, and I. Mota, "IgG subclasses responsible for immune clearance in mice infected with Trypanosoma cruzi," Immunology and Cell Biology, vol. 67, no. 6, pp. 343-348, 1989.

[61] H. A. Takehara, A. Perini, M. H. da Silva, and I. Mota, "Trypanosoma cruzi: role of different antibody classes in protection against infection in the mouse," Experimental Parasitology, vol. 52, no. 1, pp. 137-146, 1981.

[62] M. R. Powell and D. L. Wassom, "Host genetics and resistance to acute Trypanosoma cruzi infection in mice. I. Antibody isotype profiles," Parasite Immunology, vol. 15, no. 4, pp. 215-221, 1993.

[63] P. Minoprio, A. Coutinho, S. Spinella, and M. HontebeyrieJoskowicz, "Xid immunodeficiency imparts increased parasite clearance and resistance to pathology in experimental Chagas' disease," International Immunology, vol. 3, no. 5, pp. 427-433, 1991.

[64] P. Minoprio, M. C. El Cheikh, E. Murphy et al., "Xid-associated resistance to experimental Chagas' disease is IFN- $\gamma$ dependent," The Journal of Immunology, vol. 151, no. 8, pp. 4200-4208, 1993.

[65] F. Plata, F. Garcia-Pons, and J. Wietzerbin, "Immune resistance to Trypanosoma cruzi: synergy of specific antibodies and recombinant interferon gamma in vivo," Annales de l'Institut Pasteur-Immunology, vol. 138, no. 3, pp. 397-415, 1987.

[66] R. T. Gazzinelli, I. P. Oswald, S. Hieny, S. L. James, and A. Sher, "The microbicidal activity of interferon- $\gamma$-treated macrophages against Trypanosoma cruzi involves an Larginine-dependent, nitrogen oxide-mediated mechanism inhibitable by interleukin-10 and transforming growth factor$\beta$," European Journal of Immunology, vol. 22, no. 10, pp. 2501-2506, 1992.

[67] S. E. B. Graefe, B. S. Meyer, B. Müller-Myhsok et al., "Murine susceptibility to Chagas' disease maps to chromosomes 5 and 17," Genes and Immunity, vol. 4, no. 5, pp. 321-325, 2003.

[68] A. Darvasi, "Experimental strategies for the genetic dissection of complex traits in animal models," Nature Genetics, vol. 18, no. 1, pp. 19-24, 1998.

[69] L. A. C. Passos, J. K. Sakurada, A. M. A. Guaraldo, S. C. B. C. Ortiz, H. A. Rangel, and J. L. Guenet, "Chagas Fenômeno da Resistência: Identificação de regiões do Genoma importantes no controle da doença," Revista Biotecnologia Ciência \& Desenvolvimento, vol. 29, 2002.

[70] F. Iraqi, S. J. Clapcott, P. Kumari, C. S. Haley, S. J. Kemp, and A. J. Teale, "Fine mapping of trypanosomiasis resistance loci in murine advanced intercross lines," Mammalian Genome, vol. 11, no. 8, pp. 645-648, 2000.

[71] A. Galvan, F. Vorraro, W. Cabrera et al., "Association study by genetic clustering detects multiple inflammatory response loci in non-inbred mice," Genes and Immunity, vol. 12, no. 5, pp. 390-394, 2011.

[72] L. C. Peters, J. R. Jensen, A. Borrego et al., "Slc11a1 (formerly NRAMP1) gene modulates both acute inflammatory reactions and pristane-induced arthritis in mice," Genes and Immunity, vol. 8, no. 1, pp. 51-56, 2007.

[73] M. De Franco, L. C. Peters, M. A. Correa et al., "Pristaneinduced arthritis loci interact with the Slcllal gene to determine susceptibility in mice selected for high inflammation," PLoS ONE, vol. 9, no. 2, Article ID e88302, 2014.

[74] A. G. Trezena, C. M. Souza, A. Borrego et al., "Co-localization of quantitative trait loci regulating resistance to Salmonella typhimurium infection and specific antibody production phenotypes," Microbes and Infection, vol. 4, no. 14, pp. 1409-1415, 2002.

[75] J. E. Calzada, A. Nieto, M. A. López-Nevot, and J. Martín, "Lack of association between NRAMP1 gene polymorphisms and Trypanosoma cruzi infection," Tissue Antigens, vol. 57, no. 4, pp. 353-357, 2001.

[76] E. M. Silva, L. V. C. Guillermo, F. L. Ribiero-Gomes et al., "Caspase inhibition reduces lymphocyte apoptosis and improves host immune responses to Trypanosoma cruzi infection," European Journal of Immunology, vol. 37, no. 3, pp. 738-746, 2007.

[77] D. A. Farias-de-Oliveira, D. M. S. Villa-Verde, P. H. N. Panzenhagen et al., "Caspase- 8 and caspase- 9 mediate thymocyte apoptosis in Trypanosoma cruzi acutely infected mice," Journal of Leukocyte Biology, vol. 93, no. 2, pp. 227-234, 2013.

[78] G. A. Martins, A. P. Campanelli, R. B. Silva et al., "CD28 is required for $\mathrm{T}$ cell activation and IFN-gamma production by 
CD4 + and CD8 + T cells in response to Trypanosoma cruzi infection," Microbes and Infection, vol. 6, no. 13, pp. 1133-1144, 2004.

[79] C. R. F. Marinho, L. N. Nuñez-Apaza, R. Martins-Santos et al., "IFN- $\gamma$, but not nitric oxide or specific IgG, is essential for the in vivo control of low-virulence Sylvio X10/4 Trypanosoma cruzi parasites," Scandinavian Journal of Immunology, vol. 66, no. 2-3, pp. 297-308, 2007.

[80] W. O. Dutra, O. A. Martins-Filho, J. R. Cançado et al., "Chagasic patients lack CD28 expression on many of their circulating T lymphocytes," Scandinavian Journal of Immunology, vol. 43, no. 1, pp. 88-93, 1996.

[81] V. Schmitz, E. Svensjö, R. R. Serra, M. M. Teixeira, and J. Scharfstein, "Proteolytic generation of kinins in tissues infected by Trypanosoma cruzi depends on CXC chemokine secretion by macrophages activated via Toll-like 2 receptors," Journal of Leukocyte Biology, vol. 85, no. 6, pp. 1005-1014, 2009.

[82] J. Scharfstein, D. Andrade, E. Svensjö, A. C. Oliveira, and C. R. Nascimento, "The kallikrein-kinin system in experimental Chagas disease: a paradigm to investigate the impact of inflammatory edema on GPCR-mediated pathways of host cell invasion by Trypanosoma cruzi," Frontiers in Immunology, vol. 3, article 396, 2012.

[83] M. Siqueira, L. S. Drumond, M. Gennari, V. C. Ferreira, M. H. Reis, and G. Biozzi, "Effect of genetic modification of antibody responsiveness on resistance to Toxoplasma gondii infection," Infection and Immunity, vol. 48, no. 2, pp. 298-302, 1985.

[84] A. C. Corsini, R. Braz, D. B. Ciampi, and M. R. L. Zucato, "Resistance to Trypanosoma cruzi infection in relation to the timing of IgG humoral response," Zeitschrift fur Parasitenkunde, vol. 68, no. 1, pp. 15-25, 1982.

[85] P. Minoprio, O. Burlen, P. Pereira et al., "Most B cells in acute Trypanosoma cruzi infection lack parasite specificity," Scandinavian Journal of Immunology, vol. 28, no. 5, pp. 553-561, 1988.

[86] P. Minoprio, A. Bandeira, P. Pereira, T. Mota Santos, and A. Coutinho, "Preferential expansion of Ly-1 B and CD4- CD8- T cells in the polyclonal lymphocyte responses to murine T. cruzi infection," International Immunology, vol. 1, no. 2, pp. 176-184, 1989.

[87] S. E. B. Graefe, T. Streichert, B. S. Budde et al., "Genes from Chagas susceptibility loci that are differentially expressed in T. cruzi-resistant mice are candidates accounting for impaired immunity," PLoS ONE, vol. 1, no. 1, article e57, 2006.

[88] O. A. Sant'Anna, V. C. Ferreira, M. H. Reis et al., "Genetic parameters of the polygenic regulation of antibody responsiveness to flagellar and somatic antigens of Salmonellae," Journal of Immunogenetics, vol. 9, no. 3, pp. 191-205, 1982.

[89] C. M. Ayo, M. M. O. Dalalio, J. E. L. Visentainer et al., "Genetic susceptibility to chagas disease: an overview about the infection and about the association between disease and the immune response genes," BioMed Research International, vol. 2013, Article ID 284729, 13 pages, 2013.

[90] A. F. Frade, P. C. Teixeira, B. M. Ianni et al., "Polymorphism in the alpha cardiac muscle actin 1 gene is associated to susceptibility to chronic inflammatory cardiomyopathy," PLoS ONE, vol. 19, Article ID e83446, 2013.

[91] A. F. Frade, C. W. Pissetti, B. M. Ianni et al., "Genetic susceptibility to chagas disease cardiomyopathy: involvement of several genes of the innate immunity and chemokinedependent migration pathways," BMC Infectious Diseases, vol. 13, article 587, 2013. 


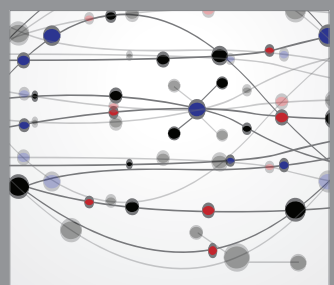

The Scientific World Journal
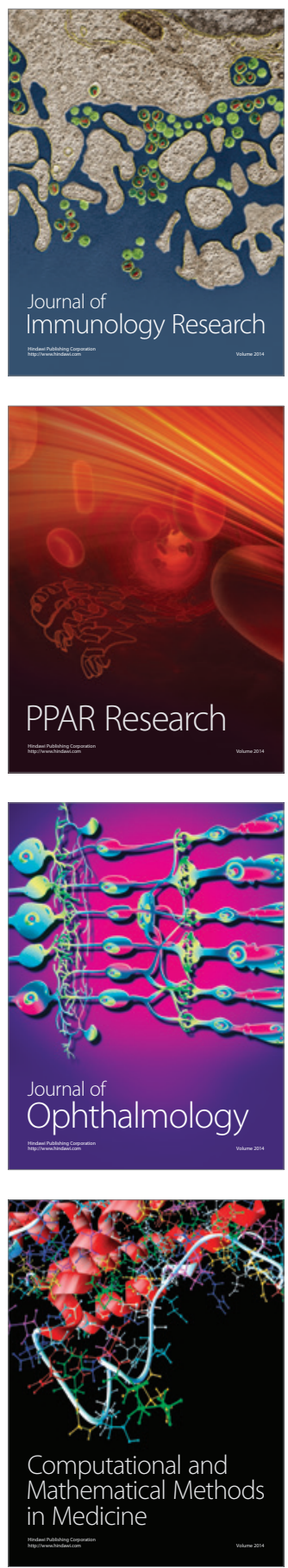

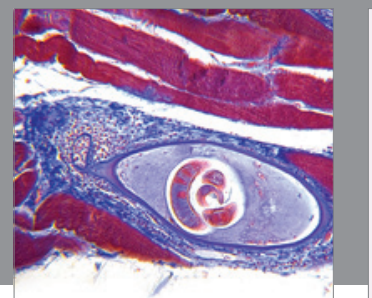

Gastroenterology

Research and Practice
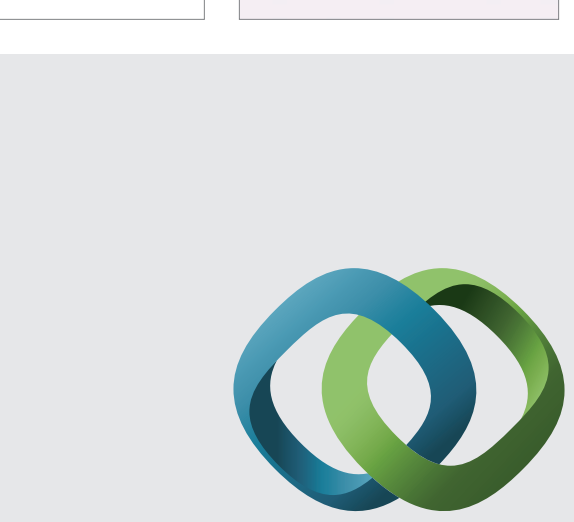

\section{Hindawi}

Submit your manuscripts at

http://www.hindawi.com
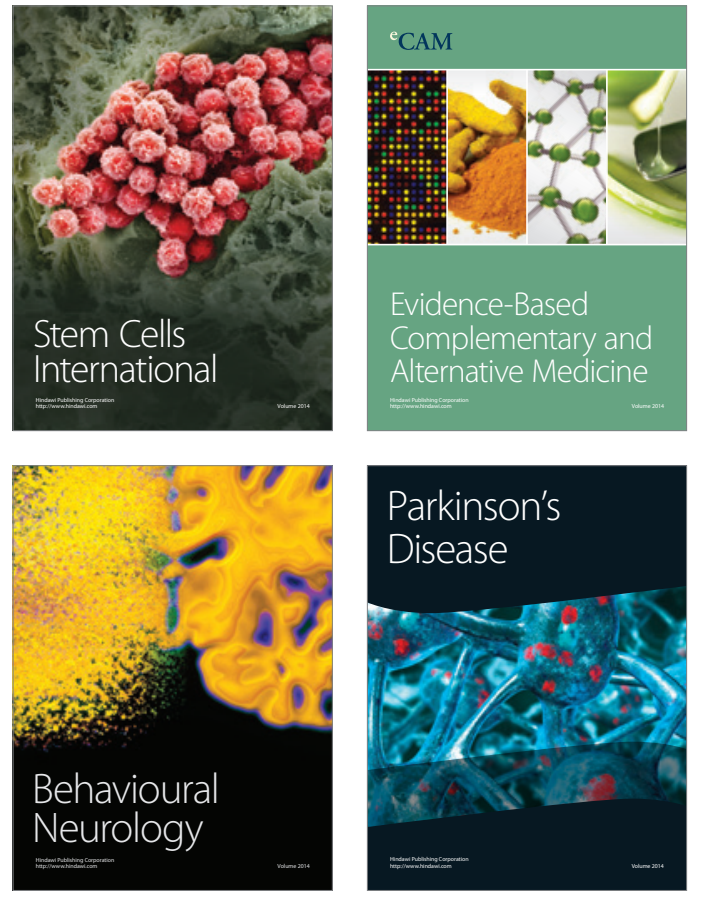
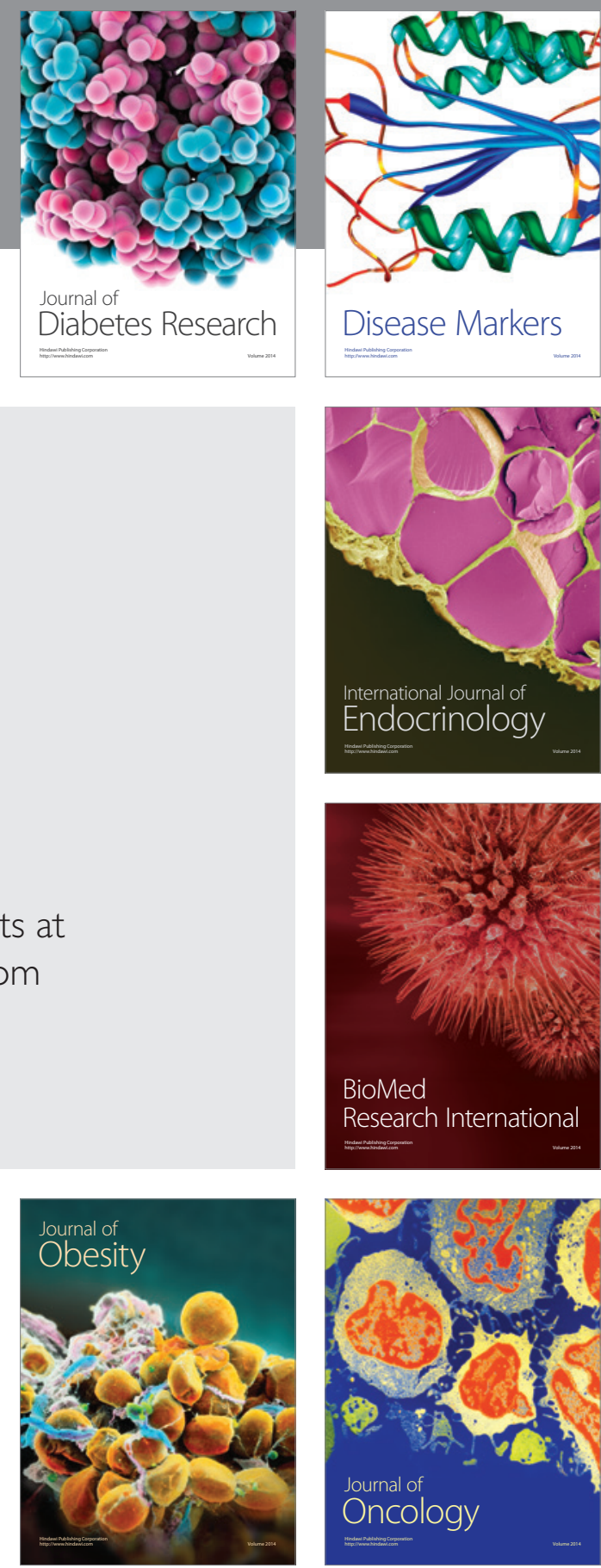

Disease Markers
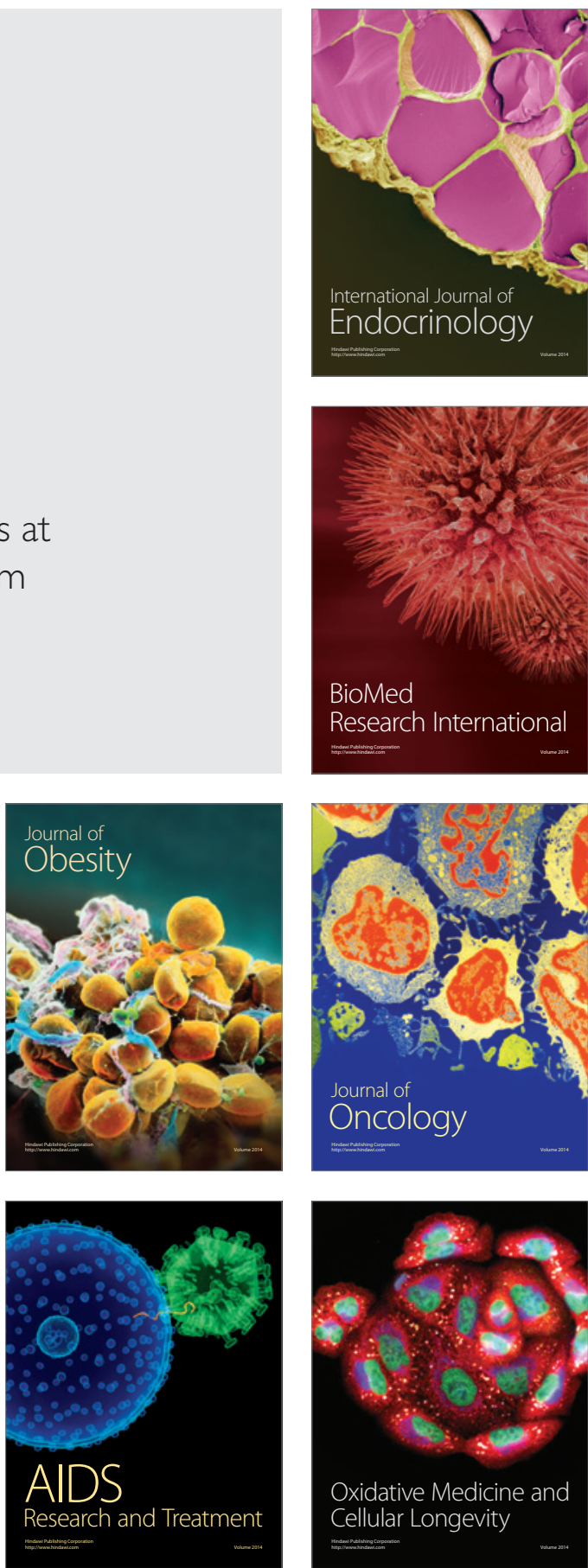